\title{
Participação democrática em ambientes digitais: o desenho institucional do orçamento participativo digital
}

Júlio Cesar Andrade de Abreu

Universidade Federal Fluminense / INSTITUTO de CIÊNCIAS HuMANAS E SOCIAIS, Programa de Pós-graduação em Administração, Volta Redonda - RJ, Brasil

\begin{abstract}
Resumo
O estudo do desenho institucional é reconhecido como fundamental para a análise do alcance de experiências participativas, e pode ser definido como a forma como se configuram as instituições políticas do Estado. Este trabalho objetiva analisar o desenho institucional do orçamento participativo digital (OPD) da Prefeitura Municipal de Belo Horizonte (PBH). Os procedimentos metodológicos usam entrevistas em profundidade, análise documental e análise de conteúdo das postagens dos cidadãos no site do OPD, do qual foram analisadas as três primeiras edições. Conclui-se que o desenho institucional do OPD favorece a ampliação quantitativa de participantes, mas, ao mesmo tempo, limita o potencial de debate democrático dessa ferramenta.
\end{abstract}

Palavras-chave: Orçamento Participativo Digital. Desenho Institucional. Participação Democrática.

\section{Democratic Participation in Digital Settings: The Institutional Design of Digital Participatory Budget}

\begin{abstract}
Studying the institutional design is recognized as crucial to analyze the scope of participatory experiences, and it may be defined as the way how the State's political institutions are shaped. This paper aims to analyze the institutional design of the digital participatory budget (DPB) by the Belo Horizonte City Hall (BHCH). The methodological procedures resort to in-depth interviews, documentary analysis, and content analysis of postings by citizens on the website of DPB, through which its first three editions were analyzed. It is concluded that the institutional design of DPB favors the quantitative expansion of participants, but, at the same time, it constraints the potential for democratic debate of this tool. Keywords: Digital Participatory Budget. Institutional Design. Democratic Participation.
\end{abstract}

\section{La Participación Democrática en Medios Digitales: El Diseño Institucional del Presupuesto Participativo Digital}

\section{Resumen}

El estudio del diseño institucional es reconocido como fundamental para el análisis del alcance de las experiencias de participación y, en efecto, se puede definir como la forma de configurar las instituciones políticas del estado. Este trabajo tiene como objetivo analizar el diseño institucional del presupuesto participativo digital (PPD) de la Municipalidad de Belo Horizonte - Brasil (MBH). Los procedimientos metodológicos utilizados emplearon entrevistas en profundidad, análisis de documentos y análisis de contenido de los mensajes de los ciudadanos en la página web de PPD, de los cuales se analizaron las tres primeras ediciones. Llegamos a la conclusión de que el diseño institucional de OPD favorece la expansión cuantitativa de los participantes, pero al mismo tiempo, limita el potencial de debate democrático de esta herramienta. Palabras clave: Presupuesto Participativo Digital. Diseño institucional. La participación democrática. 


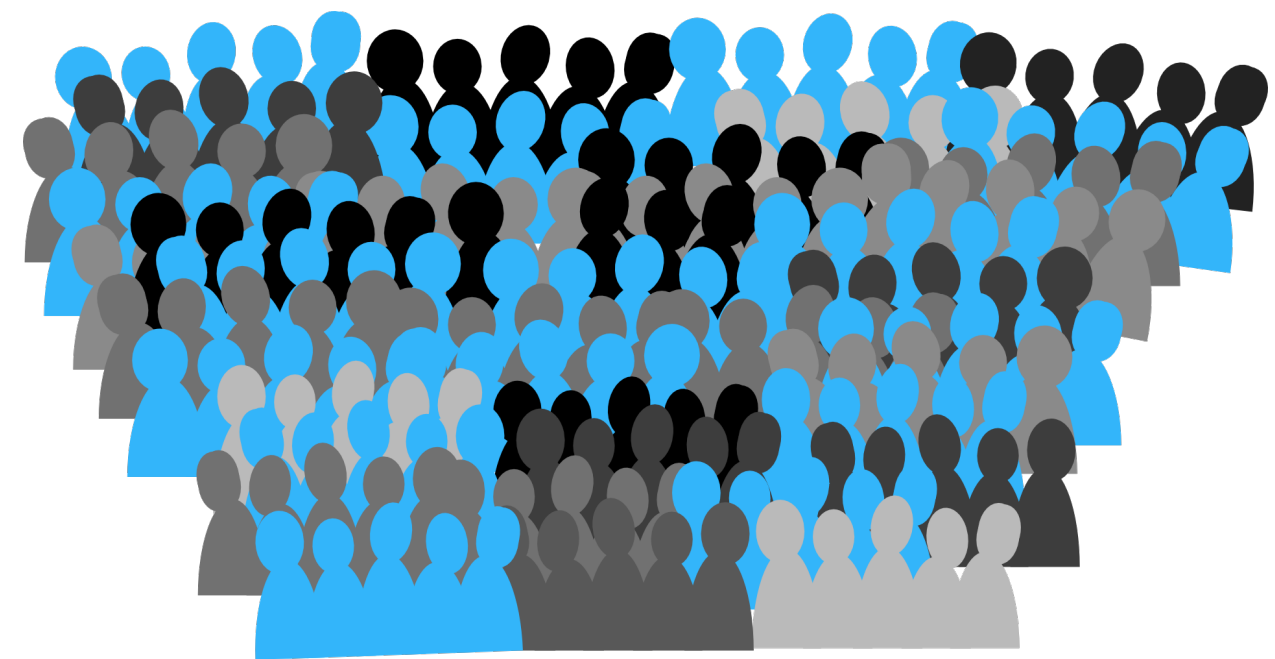

\section{INTRODUÇÃO}

A gestão pública está vivendo grande tensão entre polos opostos, pois é uma área que sofre pressões das mais diversas naturezas e intensidades. Um extremo, mais participacionista, demanda descentralização, controle social, transparência e abertura ao debate popular. Outro remete a temas como eficiência no gasto público, resultados, qualidade, agilidade e menos "burocracia" nos processos públicos. Essa tensão tem traços contraditórios, exigindo da gestão pública agilidade no processo de tomada de decisões e, ao mesmo tempo, debate com e participação da população, por exemplo.

Vivemos um tempo paradoxal. Para Santos (2002), temos plenas condições técnicas e econômicas de acabar com todas as mazelas mundiais. Fome, mortalidade infantil, diversas doenças que ainda matam milhões de pessoas pelo mundo e tantos outros absurdos já poderiam ter sido extintos. O discurso sobre a modernidade do século XX tinha isso como uma promessa (SANTOS, 2002). É curioso notar que o cumprimento dessa promessa nunca esteve tão tecnicamente viável e tão concretamente distante.

A eminência do individualismo na sociedade, somada ao distanciamento entre a gestão pública e os cidadãos, contribui para uma visão mais imediatista no atendimento de demandas individuais (NOGUEIRA, 2005). A influência do modelo gerencialista na administração pública e a lógica neoliberal trouxeram ainda a figura de um cidadão "consumidor", o que, por sua vez, reforçou a exigência por mais resultados, eficiência e técnica na gestão pública (SILVA, 2003).

Outro ponto de forte influência na gestão pública é a afirmação categórica nas últimas décadas da ideia de participação, sobretudo no Sul do mundo e, em especial, no Brasil. A participação tida de início como elemento transformador das sociedades (MARQUETTI, CAMPOS e PIRES, 2008; SANTOS, 2002; SANCHEZ, 2002) por provocar uma partilha do poder de influência das agendas públicas, se populariza. Para Santos, Sampaio e Rossi (2006, p. 3):

O convite à participação, nas duas últimas décadas, tem permeado o discurso dos mais distintos segmentos sociais, chegando mesmo a perpassar uma ampla gama de matizes políticas. De modo correlato aos conceitos de sustentabilidade e de democratização, a participação tem se constituído quase como unanimidade. Com a ampliação do espectro político, durante décadas, polarizado entre forças

* Fontes: Disponível em:<https://pixabay.com/pt/multid\%C3\%A3o-pessoas-democracia-296520/>. Acesso em 15 jun. 2016. 
genericamente qualificadas como conservadoras e democráticas, diversifica-se o leque dos atores sociais que reivindicam a incorporação da participação no processo de gestão da res publica, passando essa a ser um elemento chave na implementação das políticas públicas nas distintas esferas e escalas.

Milani (2008, p. 552), concorda com esse argumento ao afirmar que

[...] a participação social tornou-se, nos anos 1990, um dos princípios organizativos, aclamado por agências nacionais e internacionais, dos processos de formulação de políticas públicas e de deliberação democrática em escala local. Fomentar a participação dos diferentes atores políticos e criar uma rede que informe, elabore, implemente e avalie as políticas públicas são, hoje, peças essenciais nos discursos de qualquer política pública (auto)considerada progressista.

Um dos ícones desse revigoramento do discurso participativo foi, sem dúvida, o orçamento participativo (OP) (AVRITZER e NAVARRO, 2003; SANTOS, 2002; FEDOZZI, 2007). Umas das características do OP é a criação de uma verdadeira arena pública para o debate e a negociação que, na visão de Marques (2008) se constitui em uma arena de disputa entre interesses hegemônicos e contra-hegemônicos.

Na visão de Avritzer (2000 apud SANCHEZ, 2002, p. 25),

[...] a proposta de orçamento participativo foi gerada na intersecção entre sociedade civil e administração estatal, o que possibilitou que a identificação de um tema contencioso - no caso, o orçamento - fosse transformado em uma proposta de participação dos atores comunitários na elaboração do orçamento.

O OP, como tecnologia de participação, conforme explana Nunes (2006) tem uma metodologia que varia de acordo com a realidade de cada município. Não há um formato padrão. Em linhas gerais, no entanto, a maioria das experiências segue uma série de eventos encadeados, "considerando-se a etapa de elaboração, a discussão do orçamento popular, sua apreciação, execução e avaliação" (GONÇALVES, 2005, p. 47). Tal sequência é realizada normalmente por meio de assembleias populares, abertas à participação direta de todos os cidadãos e cidadãs; fóruns em que a participação acontece por intermédio de delegados eleitos pelos participantes da assembleia; e plenárias com participação aberta a todos os munícipes.

Com o avanço da democratização e da diferenciação social, ocorreu uma progressiva valorização da democracia participativa entre técnicos, gestores, estudiosos e mesmo reformadores (NOGUEIRA, 2005). A participação vista com maus olhos por tornar o processo decisório "lento", passou gradativamente a ser incorporada às rotinas e ao ementário de agências internacionais de financiamento e de diversas outras instituições. Atualmente, a participação é, portanto, aceita por todos do espectro político e ideológico (ROSAS e SANTOS, 2009; NOGUEIRA, 2005).

Tem-se, desse modo, uma nova pressão sobre a gestão pública, seja por parte da população, seja da mídia ou, mesmo, de organismos internacionais que, em alguns casos, condicionam recursos à participação popular (CUNHA e POZZEBON, 2009).

Essa dupla pressão, aqui chamada de gerencialista e participacionista, pode ser somada a outras que colocam a gestão pública em processo de constante tensão. Para Monteiro (2007), há forte pressão para o crescimento econômico e mesmo para a aplicação de reformas que eliminem os gargalos institucionais ao crescimento. Portilho (2005) aponta para pressões exercidas pelo movimento ambientalista, ao passo que Cabral, Gomes e Araujo (2010) indicam pressão política por conta do empresariado, por meio da Confederação Nacional da Indústria (CNI) sobre questões públicas. Nogueira (2005) sintetiza as pressões em quatro grandes fontes: o mercado, o transnacional, o subnacional e a sociedade civil, além de combinações diversas entre essas fontes, conforme apresentado na Figura 1. 
Figura 1

Fontes geradoras de pressão sobre a gestão pública.

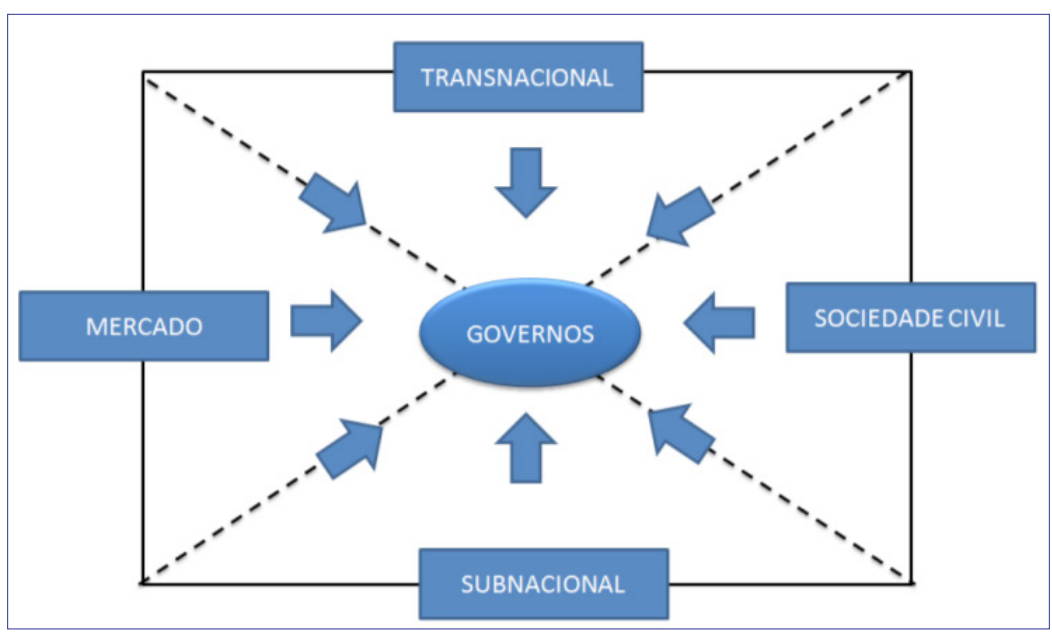

Fonte: Nogueira (2005, p. 126).

Em um primeiro polo de pressões (combinação entre as fontes transnacionais e subnacionais), Nogueira (2005) aponta as demandas que estariam fora da lógica territorial dos governos, como as regionais e de governos locais, determinações de políticas econômicas dos governos centrais, empresas multinacionais, bancos especuladores etc. Um segundo eixo, iria do mercado à sociedade civil, um com interesse no lucro e outro com interesse em afirmações de direitos e valores (NOGUEIRA, 2005).

A gestão pública responde a essas diferentes pressões de modos distintos: aos interesses transnacionais, a resposta é normalmente abertura econômica; aos subnacionais, a descentralização é a atitude mais comum; às pressões do mercado, a resposta mais recorrente é a privatização; e, quanto às demandas da sociedade civil, a resposta mais comum é a participação (NOGUEIRA, 2005). Esta, nesse sentido, é ao mesmo tempo "demanda social e uma resposta governamental" (NOGUEIRA, 2005, p. 129).

Para Milani (2008, p. 553), a participação vem como resposta governamental, mais especificamente à necessidade de políticas públicas efetivas e de controle democrático, com

[...] estratégias de descentralização, a adoção de mecanismos de responsabilização dos gestores (responsiveness e accountability), a gestão pública por resultados, o incremento do controle social, além de dispositivos de participação social que visam chamar cidadãos e organizações cívicas para atuarem como atores políticos da gestão pública. [...] a crise do modelo burocrático de administração pública evidencia com maior centralidade a crise do Estado (como corolário de uma crise econômica) que não logra atender às demandas geradas pela população de forma satisfatória; diante da crise, afirmam que o aparato do Estado deveria primar pela eficiência, eficácia e efetividade das ações, avaliando os processos e resultados de modo a possibilitar a reorientação estratégica da administração pública de forma tempestiva.

O que se percebe é um movimento simultâneo e oposto, principalmente se considerarmos a forte presença das tecnologias na contemporaneidade.

Ao mesmo tempo que esse distanciamento substantivo entre a gestão pública e os cidadãos acontece, novos processos tecnológicos promovem justamente o oposto. As novas tecnologias da informação e da comunicação (TIC) aproximam as pessoas e as organizações, conectam freneticamente os indivíduos por meio do celular, da internet e de tantos outros modos. As TIC influenciam a economia, a sociedade, a cultura, o sistema democrático e o Estado com sua administração (PINHO, 2011). Desse modo, a gestão pública que passou por tantas reformas e foi objeto de várias transformações empreendidas pelos Estados nacionais sofreu outra mudança marcante nas duas últimas décadas do século XX. 
Seus processos, técnicas e estrutura sofreram influência das novas tecnologias. Tudo para conferir mais agilidade aos processos e serviços públicos importando, muitas vezes, técnicas do setor privado, em vários momentos, nas reformas empreendidas. West (2005, p. 7, tradução nossa) advoga que "os governos do mundo inteiro criaram sites que facilitam o turismo, as queixas dos cidadãos e o investimento empresarial".

Percebe-se, na atualidade, que os estudos sobre a participação ingressam em uma fase de maior crítica. Sendo assim, a avaliação dos experimentos participativos na gestão pública já pode se feita em mais profundidade, dada sua maturidade e, sobretudo, as mudanças ocorridas na sociedade provocadas especialmente pelas TIC. Novas modalidades de participação começam a surgir, como o orçamento participativo digital (OPD), ao mesmo tempo que o individualismo, a ojeriza à política (NOGUEIRA, 2004) e a generalização da ideia de participação se tornam constantes.

\section{Figura 2}

\section{Pressões e contradições na gestão pública.}

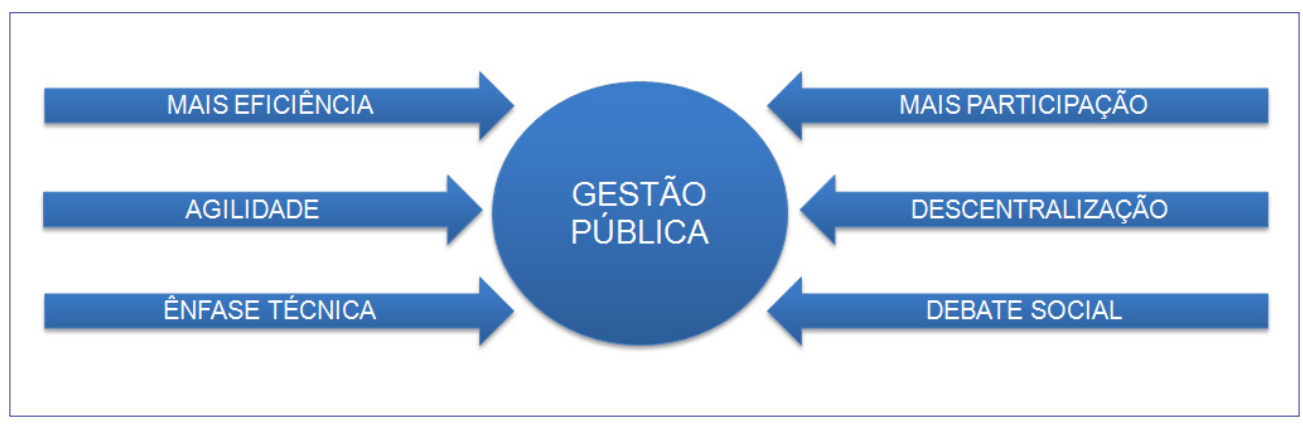

Fonte: Elaborada pelo autor.

O cenário desnudado é contraditório: uma gestão pública pressionada para ser, ao mesmo tempo, ágil e descentralizada, eficiente e rápida, participativa e que estimule o debate social, tudo isso em um contexto de grande individualismo e forte influência das novas tecnologias.

Surge como muito oportuna a pesquisa sobre artefatos e experiências de participação democrática mediadas pelas TIC. Este trabalho lança olhar sobre o OPD (estudado em diversos trabalhos como Abreu e Pinho (2014) e Cunha, Coelho e Pozzebon (2014) na cidade de Belo Horizonte. Tomando como recorte temporal o período de 2006 a 2011, consideramos as três edições do OPD da capital mineira com o objetivo de analisá-lo mediante seu desenho institucional. Como metodologia foram adotadas entrevistas em profundidade, análise documental e análise de conteúdo das postagens dos cidadãos no site do OPD.

Este trabalho está organizado do seguinte modo: além desta introdução, foi desenvolvido um referencial teórico sobre o OPD, seu desenho institucional e a participação democrática. Em seguida apresenta-se o percurso metodológico. $O$ tópico seguinte desenvolve a análise dos dados. Por último são apresentadas as conclusões desta pesquisa.

\section{DESENHO INSTITUCIONAL E PARTICIPAÇÃO ${ }^{1}$}

O Brasil, ao longo do século XX, transformou-se de um país de baixa propensão participativa e associativa para um dos países que mais vivenciam experiências e práticas participativas (AVRITZER, 2008). Contudo, imaginar que a simples ampliação dos canais de participação e de experimentos participativos irá alterar substancialmente o cenário político brasileiro é um equívoco. Para Lüchmann $(2009$, p. 2), as possibilidades e as potencialidades de participação devem ser analisadas com parcimônia, pois vários estudos sobre experiências participativas vêm "apontando uma série de dificuldades no estabelecimento de

${ }^{1}$ Cabe destacar que existe amplo debate no contexto nacional sobre experiências de participação democrática mediadas pela internet, como Abreu e Pinho (2014); Pinho (2011); Sampaio (2011), entre outros. Entretanto, dado o enfoque desta pesquisa, esses estudos não foram mobilizados no referencial teórico. 
processos efetivamente democráticos, sinalizando para um olhar mais cauteloso acerca das promessas e expectativas que a introdução da participação da sociedade civil nesses espaços sugere". Ainda que a participação tenha, efetivamente, grande potencial de divisão do poder político e mesmo de redistribuição de renda ${ }^{2}$, tal cenário não parece ser algo generalizável.

Para Frey (2003, p. 170), o determinante para um projeto de participação democrática é o desenho institucional. Segundo o autor, "o que os recentes estudos sobre experiências brasileiras em democracia local mostram é que inovações concernentes ao desenho institucional fazem de fato a diferença, não apenas para a ampliação da participação política, mas também para o fortalecimento da sociedade civil local". Serafim (2007), corroborando Frey (2003), defende que o estudo do desenho institucional é reconhecido como fundamental para a análise do alcance de experiências participativas, tendo ganhado notoriedade em estudos encampados por Silva (2003), Avritzer e Navarro (2003), entre outros.

Para Marques (2008), o desenho institucional pode ser definido como a forma como se configuram as instituições políticas do Estado. Já na visão de Lüchmann (2009), esse desenho é considerado determinante para o maior ou menor sucesso de experiências participativas. A autora define desenho institucional como um

[...] conjunto de regras [...] utilizadas por indivíduos para determinar quem e o que está incluído em situações de decisão, como se estrutura a informação, quais as ações que podem ser tomadas e em que sequência, e como as ações individuais serão agregadas e transformadas em decisões coletivas (LÜCHMANN, 2009, p. 7).

A ideia de desenho institucional envolve, na análise de Marques (2008, p. 141) uma série de nuances como

[...] um jogo intrincado de relações entre agentes políticos de diferentes naturezas; de categorias teóricas oriundas dos distintos modelos de democracia; e de conjuntos diversos de fenômenos a reverberarem sobre as práticas políticas. Ou seja, quando se pensa em desenho institucional, a discussão pode recair sobre questões tão amplas como: as crenças ideológicas e de princípios a orientarem as modificações promovidas na estrutura do Estado a médio e longo prazo; o modo a partir do qual estão dispostos os sistemas eleitorais; a maior ou menor centralização das decisões de governo e de elaboração de políticas públicas; as responsabilidades e jurisdições de agentes e de entidades políticas; o grau de independência do Poder Judiciário e a afinidade com seus órgãos de controle; a relação de poder entre o Executivo e o Legislativo; e, não menos importante, as formas de interação do Estado com os cidadãos e os movimentos organizados da sociedade civil.

Para Fung (2006), o emprego do desenho institucional carrega em si potencialidades e limites ${ }^{3}$. Lüchmann (2009) argumenta que o potencial do desenho institucional reside em três pilares: (i) estabilidade; (ii) modelagem comportamental; e (iii) ancoramento cultural. $O$ detalhamento de cada pilar pode ser observado no quadro a seguir:

\footnotetext{
${ }^{2}$ Sobre esse tema, ver Marquetti, Campos e Pires (2008), que faz uma interessante análise de diferentes experiências participativas no Brasil por meio de um método homogêneo, focando, principalmente, números e dados acerca do efeito redistributivo gerado para a sociedade.

${ }^{3}$ Para o autor o desenho institucional deve ser explorado a partir de três questões centrais, quais sejam: quem participa; como participa e como toma decisões (FUNG, 2006, p. 4).
} 


\section{Quadro 1}

\section{Potencial do desenho institucional}

\begin{tabular}{|c|c|}
\hline Potencial & Descrição \\
\hline Estabilidade ou durabilidade & $\begin{array}{l}\text { Este é um importante caráter das instituições que se constitui em um conjunto de } \\
\text { regras (ou normas) que, mais ou menos formalizadas, organizam - de alguma forma - } \\
\text { as diferentes atividades sociais (LÜCHMANN, 2009). }\end{array}$ \\
\hline Modelagem comportamental & $\begin{array}{l}\text { As instituições regularizam, modelam ou impactam comportamentos. A questão central } \\
\text { da vertente neoinstitucional está ancorada na ideia básica de que, embora os indivíduos } \\
\text { elaborem as regras, as normas e as condutas, são limitados e condicionados por } \\
\text { escolhas passadas [...]. Por outro lado, ao mesmo tempo que as instituições constrangem } \\
\text { comportamentos, também "empoderam" (empowered) os atores sociais, estruturam } \\
\text { novas agendas, mudam preferências e comportamentos sociais (LÜCHMANN, 2009). }\end{array}$ \\
\hline $\begin{array}{l}\text { Ancoramento cultural e influência } \\
\text { na correlação de interesses }\end{array}$ & $\begin{array}{l}\text { As instituições não apenas apresentam um importante ancoramento cultural, como } \\
\text { também sofrem importantes influências e mudanças advindas das correlações de } \\
\text { interesses e forças sociais. Nesse sentido, há que se resgatar e ressaltar o caráter } \\
\text { aberto e contingente das lutas e conflitos sociais no processo de organização - ou } \\
\text { reorganização - institucional. Ou seja, recuperar o papel da "agência humana" na } \\
\text { estruturação da vida político-social. Mais especificamente, na construção e/ou na } \\
\text { formatação do desenho institucional (LÜCHMANN, 2009). }\end{array}$ \\
\hline
\end{tabular}

Fonte: Adaptado de Lüchmann (2009).

A própria Teoria Política e também a Teoria Democrática (MARQUES, 2008; AVRITZER, 2008) não estão em plena concordância sobre o peso do desenho institucional em processos participativos, apresentando, em alguns casos, divergências entre as posições de Frey (2003) e Lüchmann (2009).

Putnam (1993), ao avaliar três fatores (i) desenho institucional; ii) questões socioeconômicas; e iii) aspectos socioculturais) para compreender o comportamento político de cidadãos no norte e no sul da Itália, dá interessante contribuição para essa seara de debate. Acerca do primeiro fator, Putnam (1993, p. 8, tradução nossa) aplica um duplo olhar:

Tomando as instituições como uma variável independente, exploramos empiricamente como a mudança institucional afeta as identidades, o poder e as estratégias dos atores políticos. Mais tarde, tendo as instituições como variável dependente, vamos explorar como o desempenho institucional é condicionado pela história.

Desse prisma, o autor conclui que o desenho institucional tem fraca influência sobre a participação da sociedade civil e observa que, mesmo tendo os mesmos instrumentos e estando no mesmo cenário institucional, a participação da sociedade civil italiana se expressa em diferentes comportamentos no norte e no sul. Tal situação conduz a uma explicação das diferenças de comportamento político que não reside no desenho institucional.

O estudo de Putnam (1993) aponta uma fragilidade do conceito de desenho institucional como categoria de análise. Entretanto, Frey (2003, p. 170), defendendo a aplicação do desenho institucional, critica a visão de Putnam rotulando-a de fatalista "na medida em que as raízes históricas e culturais são sobrevalorizadas". Maloney et al. (2000 apud FREY, 2003, p. 170) entendem que, ao considerar o Estado um fator exógeno, Putnam "negligencia o papel desempenhado por estruturas políticas e instituições em moldar o contexto da atividade associativa".

Segundo Frey (2003), deve-se levar em conta o papel dos arranjos institucionais para promoção, por exemplo, de canais de comunicação que propiciem condições favoráveis à participação democrática. Nesse sentido, Marques (2008) argumenta que os fatores socioculturais e econômicos são importantes, mas não se deve negligenciar o papel do desenho institucional. Para Marques (2008, p. 142), Putnam "excessivamente valoriza a cultura cívica como o elemento mais fundamental a determinar o comportamento político dos cidadãos". 
Frey (2003) e Marques (2008) sugerem que o desenho institucional deva ser usado para a análise de experiências participativas, considerando tanto seus potenciais quanto seus limites, que podem ser sintetizados no quadro a seguir:

\section{Quadro 2}

\section{Limites do desenho institucional}

\begin{tabular}{|l|l|}
\hline \multicolumn{1}{|c|}{ Limite } & \multicolumn{1}{c|}{ Descrição } \\
\hline Controle e cooptação & $\begin{array}{l}\text { Em primeiro lugar, o elogio ao potencial das instituiçães para promover mudanças } \\
\text { nos padrões de ativismo e engajamento da esfera da cidadania precisa de limites } \\
\text { porque, conforme sustenta Frey (2003), é preciso ser cuidadoso no que concerne } \\
\text { às tentativas de controle e de cooptação que podem ser exercidas pela burocracia } \\
\text { estatal (MARQUES, 2008). }\end{array}$ \\
\hline $\begin{array}{l}\text { Centralização de oportunidades de } \\
\text { participação }\end{array}$ & $\begin{array}{l}\text { Há um conjunto de autores que aponta os riscos de se centralizarem as } \\
\text { oportunidades de participação apenas à dimensão institucional, ressaltando-se a } \\
\text { necessidade de manutenção de espaços de debate e de mobilização em instâncias } \\
\text { eminentemente civis (MARQUES, 2008). }\end{array}$ \\
\hline Ausência de garantias de participação & $\begin{array}{l}\text { Em segundo lugar, atente-se para o fato de que mesmo um desenho institucional } \\
\text { direcionado ao favorecimento da participação dos cidadãos não garante que tal } \\
\text { participação ocorrerá de maneira fluida e sem percalços, exatamente por conta da } \\
\text { retroinfluência de outros fatores sobre os modos de engajamento da esfera civil } \\
\text { (MARQUES, 2008). }\end{array}$ \\
\hline
\end{tabular}

Fonte: Adaptado de Marques (2008) e Frey (2003).

O que se defende aqui, partindo dos diferentes autores e visões apresentados, é que o desenho institucional não deve ser tomado como única chave analítica de experiências participativas. Apesar disso, sua importância é atestada por diversos trabalhos, entre os quais o de Avritzer e Navarro (2003). Ao analisar empiricamente o OP de Porto Alegre e o OP estadual do Rio Grande do Sul, os referidos autores concluem que o desenho institucional é uma variável central na compreensão do processo participativo, sendo mais relevante que a vontade política emanada dos governantes (no caso do OP estadual). Destarte, sua aplicação no caso do OPD pode contribuir para a melhor compreensão do problema desta pesquisa.

Fung (2006, p. 5, tradução nossa), sugere o uso de um cubo democrático para análise de experiências participativas e seu desenho institucional.

Além dessas várias formas em que as pessoas se reúnem para discutir assuntos públicos, três questões de desenho institucional são particularmente importantes para compreender o potencial e os limites de várias formas participativas: Quem participa? Como eles se comunicam e tomam decisões? Qual é a conexão entre suas conclusões e opiniões de um lado e de políticas públicas e ação sobre o outro?

Com base nessas questões são elaborados três eixos de análise: Participantes; Autoridade e Poder; e Formas de Comunicação e Processo Decisório.

Na elaboração dos eixos, Fung (2006) abarca desde as situações mais exclusivas até as mais inclusivas, criando diferentes gradientes que fazem que sua metodologia seja potencialmente aplicável, não só em processos de participação popular, mas também em outras esferas decisórias.

Outras vantagens do cubo democrático, segundo Franckini, Kyrillos, Gugliano et al. (2010) são:

1 - Trata-se de um instrumento que permite, a um só tempo, a análise de mecanismos de representação e de participação. Isso possui grande relevância, posto que se revela cada vez mais necessária, 
para determinados estudos, uma relativização desses dois conceitos e um esfumaçamento das fronteiras entre eles. 2 - Ao propor que se estudem as instâncias de participação popular por um viés "experimentalista", Fung as está tratando como experiências concretas com algum potencial para o aprofundamento da democracia, mas preocupando-se em avaliar a qualidade e o grau desse potencial em cada experiência, em vez de tomá-las imediatamente como uma espécie de panaceia para a democracia. [...] Fung não assume um tom celebratório ou otimista, mas sim uma perspectiva crítica e realista acerca das potencialidades dos mecanismos de participação popular, visando analisá-las a partir de considerações concretas acerca de seu desenho institucional.

O primeiro eixo do cubo democrático é o "Participantes". Fung (2006) entende que a forma de autorização dos tomadores de decisão (técnicos, burocratas ou representantes eleitos) no governo contemporâneo é deficiente. Entretanto, acredita que a participação direta dos cidadãos nos negócios públicos pode amenizar esse cenário.

Defendendo que "a grande maioria dos mecanismos de participação pública utilizam o método menos restritivo para a seleção de participantes: eles estão abertos a todos os que desejam participar. Participantes reais são um subconjunto autosselecionado da população em geral", Fung (2006, p. 8, tradução nossa) elabora o seguinte contínuo de gradações do eixo Participantes:

Figura 3

Método de seleção de Participantes

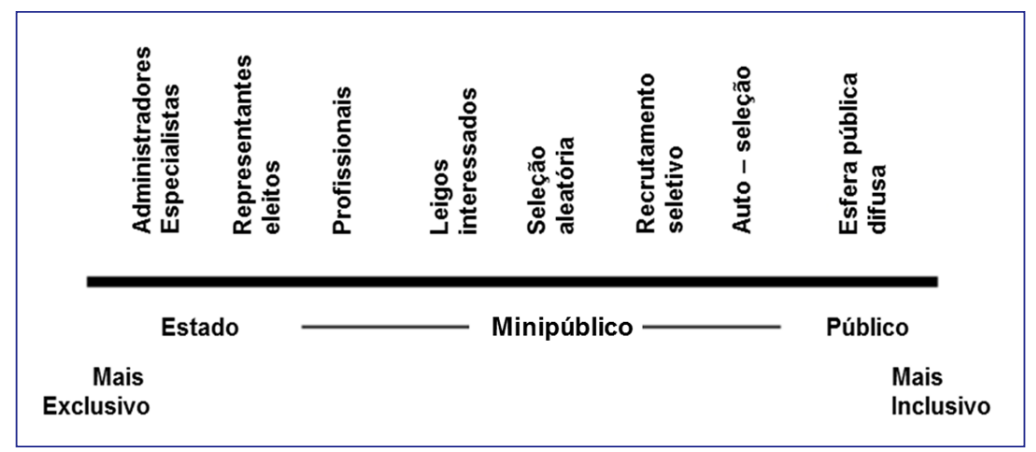

Fonte: Fung (2006, p. 8).

O eixo Formas de Comunicação e Processo Decisório, que tem uma gradação de seis níveis, envolve a ideia de como os participantes interagem e como a decisão é tomada. Os níveis desse eixo são apresentados a seguir:

Figura 4

Formas de Comunicação e Decisão

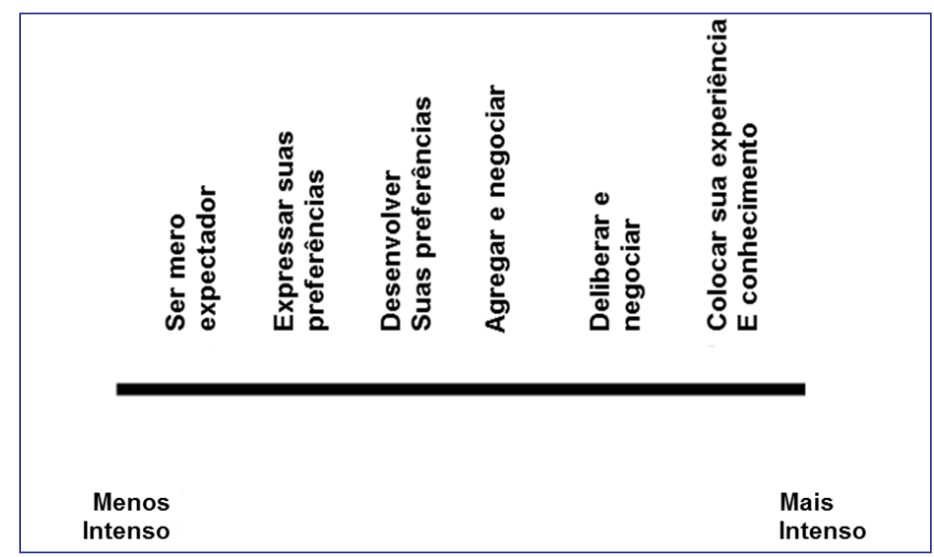

Fonte: Fung (2006, p. 11). 
Fung (2006, p. 10) argumenta que

[...] esses seis modos de comunicação (três primeiros) e tomada de decisão (segundo três) podem ser dispostos em uma única dimensão que varia do menos intenso para mais intenso, onde a intensidade indica o nível de investimento, conhecimento e compromisso exigido dos participantes.

O terceiro e último eixo refere-se à Autoridade e Poder. Nele se busca enquadrar o impacto da participação no processo decisório público. O espectro vai de um extremo, em que as decisões têm impacto na política, até um cenário mais comum (FUNG, 2006, p. 12). O eixo é apresentado na Figura 5.

Figura 5

\section{Formas de Autoridade e Poder}

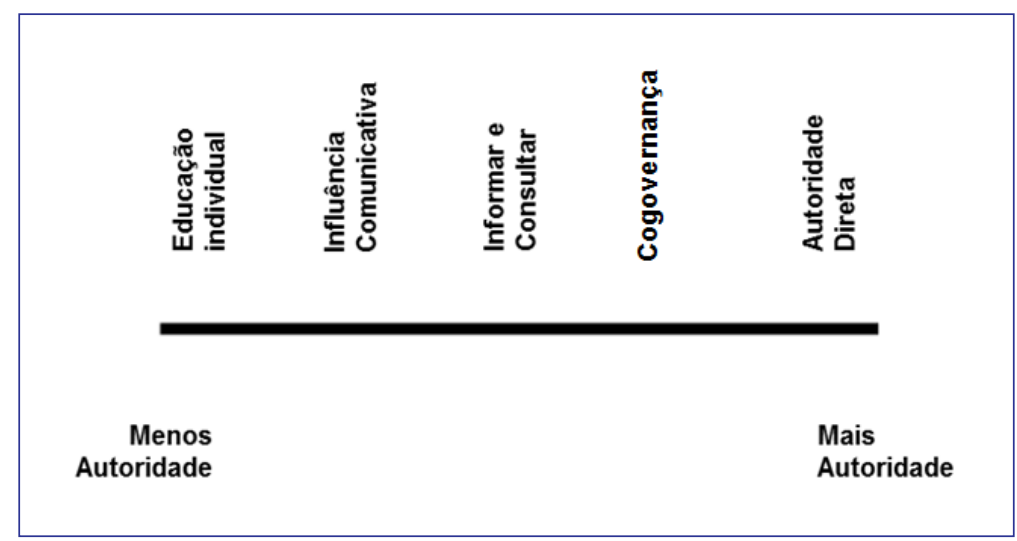

Fonte: Fung (2006, p. 14).

A Figura 6 apresenta o democracy cube de Fung (2006, p. 19).

Figura 6

\section{Cubo democrático}

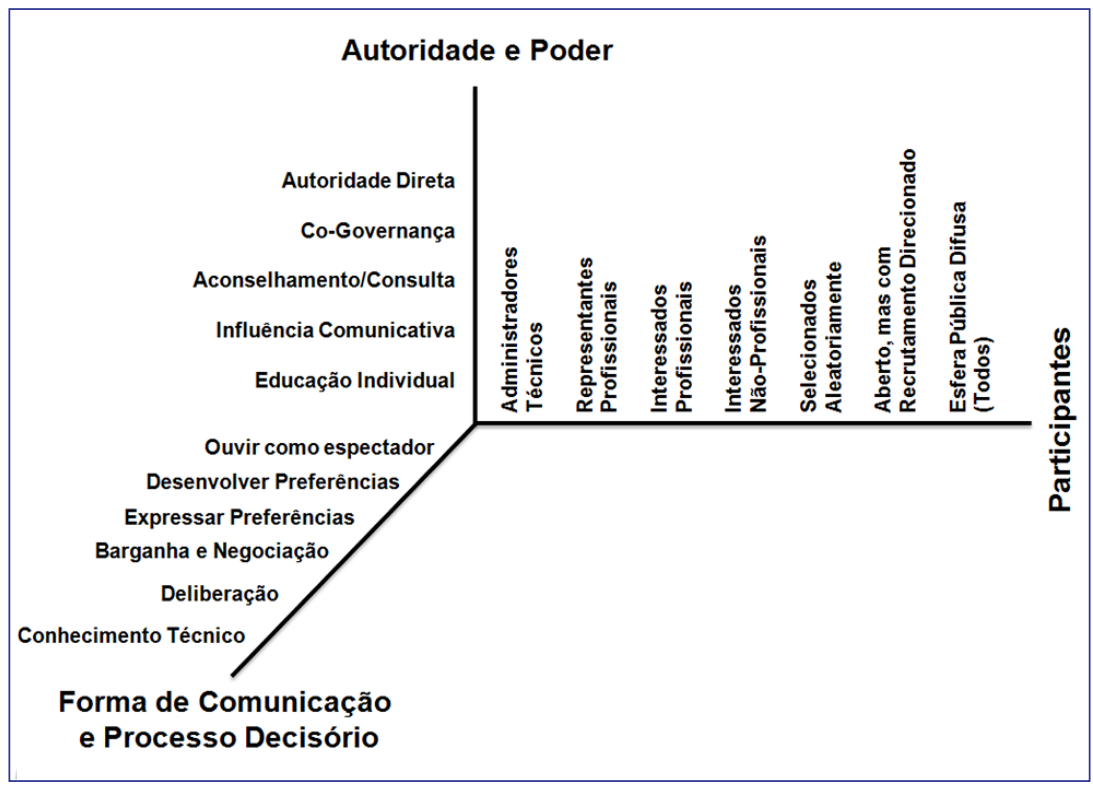

Fonte: Fung (2006, p. 19). 


\section{PERCURSO METODOLÓGICO DA PESQUISA}

Esta pesquisa adotou como método o estudo de caso, e sua natureza é qualitativa. Para Denzin e Lincoln (2000), essa natureza de pesquisa tem sido apresentada como soft science por positivistas, assumindo que a realidade social é estável e imutável, o que a tornaria candidata a estudos de natureza quantitativa, uma vez que esse tipo de pesquisa ofereceria maiores oportunidades para explicação e generalização de resultados.

Outro aspecto das pesquisas qualitativas, constantemente ressaltado, refere-se à questão da generalização de seus resultados (RICHARDSON et al., 2007; ZANELLA, 2009; FACHIN, 2001). Sobre os estudos de casos, Triviños (1987, p. 110-111) defende que "estes estudos têm por objetivo aprofundar a descrição de determinada realidade" e, por conta disso, "os resultados são válidos só para o caso que se estuda. Não se pode generalizar o resultado".

O campo de análise do caso sugere um dado recorte espaço temporal. A análise empreendida tem como escopo espacial a cidade de Belo Horizonte e as experiências entre $2006^{4}$ e 2011. A Figura 7 a seguir demonstra as atividades de coleta de dados e momentos da pesquisa ao longo do tempo.

Figura 7

\section{Linha do tempo da pesquisa}

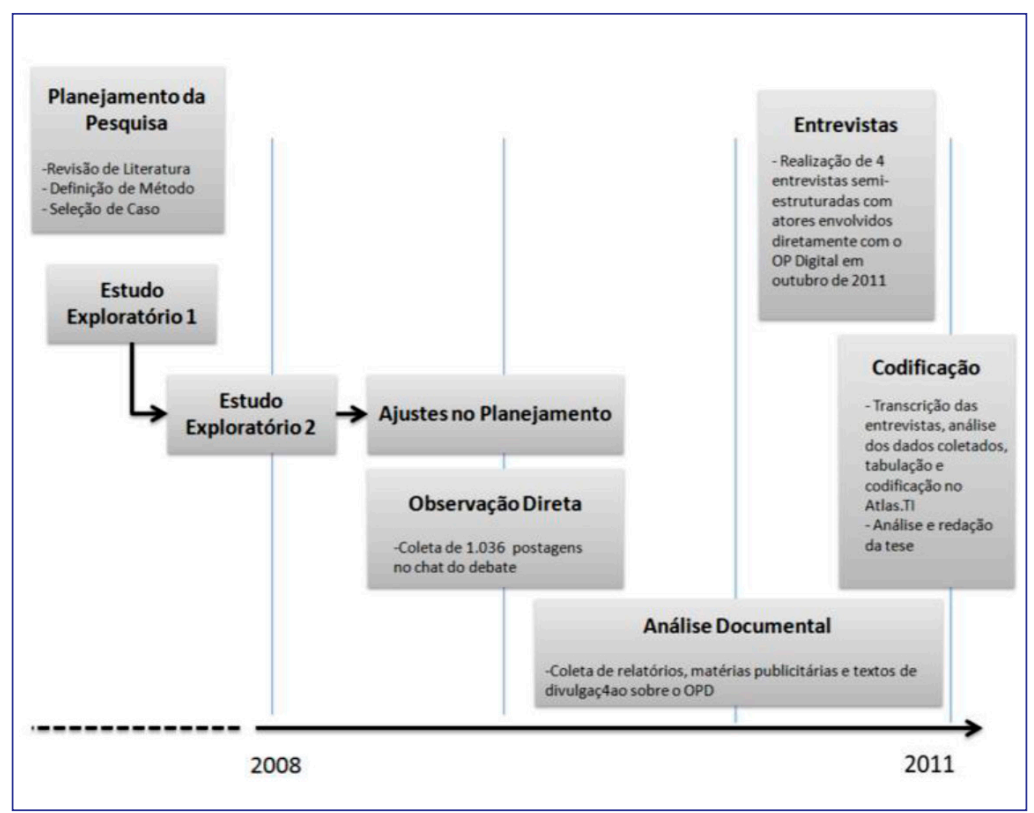

Fonte: Elaborada pelo autor.

A maneira como se deve ou se vai observar direciona-nos para o método aplicado nesta pesquisa, a coleta e o tratamento dos dados. $O$ método empregado é o estudo de caso, justificado na seção anterior.

Depois do desenvolvimento da teoria (que contou com a revisão de literatura etc.), foi selecionado o caso, projetado um protocolo de coleta e observação e da condução do caso. Durante a condução, os dados foram coletados por meio de:

a) Observação direta no sítio do OPD da Prefeitura Municipal de Belo Horizonte (PBH), no período de 20/11/2008 até 10/1/2009. Nessa observação, foram coletadas todas as postagens dos cidadãos que participaram da ferramenta chat do OPD, num total de 1.036 postagens, feitas entre 12/11/2008 e 8/12/2008.

\footnotetext{
${ }^{4}$ A maior parte dos dados, contudo, remete à edição de 2008, quando diferentes formas de interação foram desenvolvidas. A edição de 2008 é analisada e referenciada como uma "evolução" da edição de 2006.
} 
b) Entrevistas semiestruturadas com gestores públicos envolvidos com o OPD, tanto da parte de gestão como da parte técnica. De acordo com Boni e Quaresma (2005, p. 75),

As entrevistas semiestruturadas combinam perguntas abertas e fechadas, onde o informante tem a possibilidade de discorrer sobre o tema proposto. O pesquisador deve seguir um conjunto de questões previamente definidas, mas ele o faz em um contexto muito semelhante ao de uma conversa informal. $O$ entrevistador deve ficar atento para dirigir, no momento que achar oportuno, a discussão para o assunto que o interessa fazendo perguntas adicionais para elucidar questões que não ficaram claras ou ajudar a recompor o contexto da entrevista, caso o informante tenha "fugido" ao tema ou tenha dificuldades com ele.

Foram entrevistadas a secretária Municipal Adjunta de Planejamento (responsável pela condução do OPD atualmente e que esteve à frente das edições 2008 e 2011), o superintendente de Desenvolvimento de Sistemas da Prodabel (responsável pelo desenvolvimento dos sistemas do OPD), o gerente da Regional Centro-Sul (um exmilitante nos movimentos sociais) e a gestora que esteve à frente da Secretaria de Planejamento na edição de 2006.

c) Análise Documental feita em diversos relatórios e documentos divulgados pela PBH.

O quadro de entrevistas é sintetizado no quadro 3.

\section{Quadro 3}

\section{Detalhamento das entrevistas}

\begin{tabular}{|l|l|l|l|}
\hline \multicolumn{1}{|c|}{ Entrevista } & \multicolumn{1}{|c|}{ Ator/entrevistado } & \multicolumn{1}{c|}{ Atuação } & \multicolumn{1}{c|}{ Motivação para a entrevista } \\
\hline 01 & $\begin{array}{l}\text { Secretária Adjunta de } \\
\text { Planejamento }\end{array}$ & Gestor público & $\begin{array}{l}\text { Envolvido diretamente na elaboração do OPD, } \\
\text { edição 2011. }\end{array}$ \\
\hline 02 & $\begin{array}{l}\text { Superintendente de } \\
\text { Desenvolvimento de } \\
\text { Sistemas da Prodabel }\end{array}$ & $\begin{array}{l}\text { Gestor público } \\
\text { com perfil } \\
\text { técnico }\end{array}$ & $\begin{array}{l}\text { Envolvimento direto na elaboração de } \\
\text { diretrizes para o desenvolvimento da } \\
\text { ferramenta OPD (site, pontos digitais de } \\
\text { votação etc.). }\end{array}$ \\
\hline 04 & $\begin{array}{l}\text { Ex-Secretária de } \\
\text { Planejamento }\end{array}$ & Gestor público & $\begin{array}{l}\text { Envolvido diretamente na elaboração do OPD, } \\
\text { edições 2006 e 2008. }\end{array}$ \\
\hline 05 & $\begin{array}{l}\text { Gerente Regional de OP } \\
\text { com perfil de } \\
\text { ex-militante }\end{array}$ & $\begin{array}{l}\text { Envolvido com a prática do processo (reuniões } \\
\text { com o OP Regional, Comforça etc.) e em } \\
\text { constante contato com a população. }\end{array}$ \\
\hline & $\begin{array}{l}\text { Líder do Movimento Social } \\
\text { Bascílio da Gama }\end{array}$ & $\begin{array}{l}\text { Líder } \\
\text { comunitário }\end{array}$ & $\begin{array}{l}\text { Uma das lideranças de um movimento que } \\
\text { nasceu do OPD reivindicando a aprovação de } \\
\text { uma das obras. }\end{array}$ \\
\hline
\end{tabular}

Fonte: Elaborada pelo autor.

Deve-se destacar que a decisão de escolha do caso do OPD de Belo Horizonte se justifica por seu pioneirismo no cenário brasileiro e, ao mesmo tempo, por sua relevância internacional, sendo objeto de premiações na área de gestão pública (BELO HORIZONTE, 2008a).

\section{RESULTADOS E ANÁLISE}

De maneira geral, o processo de criação do OPD em Belo Horizonte foi conduzido da seguinte forma: 1) foi criado um grupo de trabalho na PBH para planejar o processo, desenvolver a metodologia de divulgação e do sistema de votação etc.; (2) foi 
feita uma pré-seleção dos empreendimentos ${ }^{5}$; (3) apresentou-se o OPD da PBH na abertura do OP Regional; (4) foi estabelecida uma parceria com o Tribunal Regional Eleitoral de Minas Gerais (TRE-MG) para fornecer ao banco de dados os eleitores para fins de validação e acesso dos cidadãos ao site do OPD; (5) foram feitas campanhas de divulgação e instalação dos equipamentos para votação em diversos pontos da cidade; (6) foram realizadas a votação (aberta durante um período predeterminado em cada edição) e a apuração dos resultados; (7) foi estabelecida a inclusão dos empreendimentos escolhidos por meio do OPD no Plano Municipal de Prioridades Orçamentárias do OP Regional 2007/2008; (8) finalmente, procedeu-se à divulgação dos resultados para a população (BELO HORIZONTE, 2007b; 2008a).

O processo de votação é simples: o cidadão acessa o site, lança o número do título de eleitor e seleciona a obra em que quer votar. Por telefone, segue-se lógica similar. O website informa em tempo real o placar da votação, contabilizando os votos pela internet, pelo telefone e por regional (NABUCO, 2008). É importante ressaltar que, nas edições seguintes (2008 e 2011), houve ajustes na metodologia.

Para permitir acesso amplo às modalidades de votação, a PBH se mobilizou para diversificar os postos de informação e de votação:

Nos Canteiros de obras da Secretaria Municipal de Políticas Urbanas foram disponibilizados telefones e computadores para os funcionários e para a comunidade votarem no OP Digital. A Secretaria Municipal de Educação distribuiu para os alunos da rede municipal panfletos de divulgação do OP Digital. A Secretaria Municipal de Saúde auxiliou na distribuição de panfletos para população via Agentes Comunitários de Saúde. A Coordenadoria da Juventude distribui material para 15.000 jovens. As Administrações Regionais intensificaram seus esforços na busca de novos pontos de inclusão digital e mobilização junto aos Conselhos e Comissões de Acompanhamento e Fiscalização do OP Regional. A Empresa de Trânsito e Transportes de Belo Horizonte - BHTRANS afixou faixas nas vias públicas indicando os locais das obras e distribuiu panfletos no entorno destas. O Call Center da Prefeitura (para informações aos cidadãos), também foi incorporado como mecanismo de divulgação do OP Digital. (BELO HORIZONTE, 2008b).

Além da mobilização da PBH, várias pessoas se organizaram para prover locais de votação. Até a elaboração desta pesquisa, em 2012, três votações foram conduzidas na modalidade do OPD. A primeira, em 2006, tinha como objetivo escolher uma obra por regional. A segunda, em 2008, referiu-se à escolha de uma grande obra viária para a cidade em um grupo de cinco opções. A terceira, em 2011, retomou o modelo de 2006, quando cada regional deveria escolher uma obra em um rol de opções previamente definido.

\section{A PARTICIPAÇÃO DEMOCRÁTICA NO OPD}

Em termos de pulverização geográfica e números absolutos de participação, o OPD, sem dúvida, chama atenção. No caso da edição 2006, foi identificada a participação de 172.938 eleitores, que votaram deliberando sobre um orçamento de $R \$$ 20.250.000,00 (NABUCO, 2008). Na edição de 2008, o número de eleitores votantes foi de 113.383 , deliberando sobre um orçamento de R\$ 50 milhões (NABUCO, 2008). Já na última edição, o número de participantes foi de 25.378 eleitores. Para efeito comparativo, o Gráfico 1 apresenta a evolução do número de eleitores ao longo do tempo no OPD.

\footnotetext{
${ }^{5}$ A pré-seleção dos empreendimentos seguiu uma metodologia própria em cada edição. Na edição de 2006, os empreendimentos/obras foram selecionados por regional e contaram com a participação da COMFORÇAS. Em 2008, a COMFORÇAS não foi diretamente envolvida e as obras foram definidas pela prefeitura com critérios técnicos, baseados no VIURBS (um Programa de Estruturação Viária de Belo Horizonte). Na edição de 2011, também não houve envolvimento direto da COMFORÇAS.
} 


\section{Gráfico 1}

Participação nas três edições do OPD.

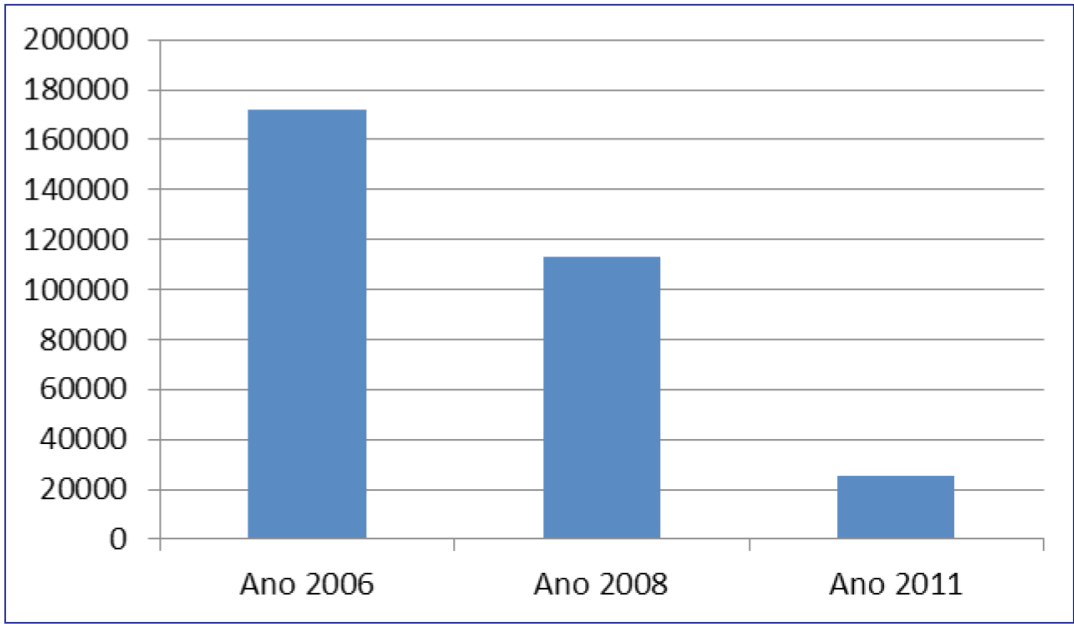

Fonte: adaptado de Belo Horizonte (2008a) e Nabuco (2008).

Em 2006, a votação das obras da Regional Centro-Sul mereceu destaque pelo processo de mobilização. Até 24 horas antes do encerramento da votação, a obra sobre a reforma da praça Raul Soares estava em terceiro lugar. Contudo, com grande mobilização dos cidadãos da regional, o placar foi invertido e a obra se sagrou vencedora. Para Abreu e Pinho (2014), o sentimento de expectativa democrática era algo latente.

Na ocasião, a PBH divulgou no site do OPD uma matéria sobre a votação da praça Raul Soares. Segundo a PBH:

Resultado da mobilização que envolveu moradores, comerciantes e usuários da região, na regional Centro-Sul o placar da votação foi alterado de forma surpreendente. Em menos de 24 horas, a obra da Praça Raul Soares saltou da terceira posição para o primeiro lugar. O Mercado Central foi um dos principais responsáveis pela evolução. Os comerciantes aderiram ao OP Digital e instalaram computadores fazendo campanha para atrair eleitores. Dois computadores foram instalados perto da Praça do Abacaxi, ao lado do elevador. Segundo o presidente do Mercado e membro do Conselho de Revitalização do Hipercentro de Belo Horizonte, Macoud Rademacker Patrocínio, o Orçamento Participativo Digital deu chance à população de exercer a sua cidadania. "A instalação da internet aqui facilita a vida das pessoas. Elas fazem compras e votam também".

Os canais de participação disponibilizados pela edição 2006 do OPD foram um chat e um fórum. Este estava organizado por regional e tinha um tópico para elogios, críticas e sugestões sobre o OPD 2006.

Foram computadas 930 postagens no fórum, distribuídas em 216 subtópicos na edição 2006. Além dos canais participativos do site, é interessante destacar o processo de definição do "menu" de obras que seguiu para votação. Segundo a PBH, o processo contou com uma definição prévia das obras por regional, adotando-se critérios técnicos. Em seguida, essa listagem prévia passou pela análise da Comforças para estruturação da lista definitiva.

Alguns dados da edição de 2008 exemplificam a capilaridade do OPD, pois ao fim "do processo de votação foram contabilizadas 217.655 visitas ao website, 593 e-mails enviados ('Fale Conosco'), na 'Opinião do Cidadão' foram postadas 1950 mensagens e 30.035 usuários indicaram o site a um conhecido" (BELO HORIZONTE, 2008b).

Belo Horizonte (2008b, p. 15) indica, no caso do OPD 2008, o processo de votação "teve início no dia 11 de novembro de 2008 e foi encerrado em 8 de dezembro do mesmo ano. Durante esses 27 dias, foram registradas [visitas], provenientes de 69 países". 
Com expressiva votação para uma experiência que está apenas na terceira edição, um dos principais objetivos da PBH foi atingido: o alargamento da participação (considerando os votantes no OPD). Certamente, o número decrescente de votantes é um aspecto que merece destaque e será analisado de maneira mais detalhada no tópico a seguir.

A participação OP Regional em Belo Horizonte foi caracterizada, em termos de número de participantes, ao longo dos anos pela inconstância. Cunha, Allegretti e Matias (2007, p. 13) reforçam essa ideia ao afirmar que:

Nos treze anos de existência do OP distrital - que se realizou em ciclos anuais de 1993 a 1998 e em ciclos bienais de 1999 a 2006 - a participação popular foi marcada por uma grande inconstância. Até 1996, assistiu-se a um alargamento progressivo nos níveis de participação, que caiu significativamente nos dois anos seguintes. A introdução de ciclos bienais levou a um novo alargamento, que se consolidou nos dois primeiros ciclos, mas esta tendência reverteu-se mais uma vez no ciclo de 2003/2004 com menos 13.000 participantes relativamente ao ciclo de 2001/2002. É neste contexto que é introduzido o OP digital. No ciclo presencial de 2005/2006 voltou a haver uma subida, aumentando o número de participantes no OP distrital em cerca de 8.000 pessoas.

Tal tentativa de alargamento não tem um cunho só quantitativo, mas também tinha a intenção de atingir novos públicos que, por razões diversas (não dispunham de tempo para participar das assembleias, o local dos debates era afastado de sua residência etc.), não participavam do OP Regional. Em especial, pretendia-se atingir os jovens que estavam, até então, dramaticamente ausentes no processo.

O "cardápio de obras" do OPD 2008 foi, diferentemente do OPD 2006, definido com base em critérios totalmente técnicos e conduzidos pela PBH. A base do processo foi o Viurbs (um Programa de Estruturação Viária de Belo Horizonte). Como a proposta da edição de 2008 não envolvia uma obra por regional, foram analisados os relatórios do Viurbs para elencar um conjunto de obras estruturantes, de grande porte para o município, na área de transporte. Cunha, Coelho e Pozzebon (2014) destacam que em 2008 a participação sofreu uma queda ainda que o telefone tenha sido inserido como método de votação ao lado da internet.

Na edição 2011, o site usado para votação foi aprimorado com vários elementos, o que o tornou mais interativo. Houve também um investimento nas redes sociais Facebook, Twitter e Orkut. A seguir, observa-se uma tela do sítio do OPD 2011 e também do Orkut da PBH.

Seguindo o exemplo da edição 2008, na edição 2011, em datas e horários previamente agendados, os eleitores tiveram a oportunidade de participar de debates sobre as obras com secretários e gestores da PBH. Nesses debates, em formato de chat, o tema em questão era definido previamente. Além dessa possibilidade, havia um fórum, no qual os eleitores poderiam postar mensagens expressando sua opinião sobre as obras. Nele, entretanto, não havia qualquer interação com a PBH.

Na edição 2011, foi disponibilizada uma área com informações sobre o histórico do OPD, recuperando o contexto de criação, as obras vencedoras e o status de sua implementação (obra executada, aguardando licitação etc.).

A seleção das obras a serem votadas na edição de 2011 foi feita a partir de critérios técnicos. A PBH informa que foram consideradas demandas não aprovadas no OP Regional e, mesmo, manifestações da população.

De maneira sintética, podemos comparar as três edições na Tabela 1. 
Tabela 1

Síntese da votação do OPD nas três edições.

\begin{tabular}{|c|c|c|c|}
\hline & OPD 2006 & OPD 2008 & OPD 2011 \\
\hline Tipo de votação & Obras por regional & $\begin{array}{c}\text { Grande obra viária para } \\
\text { a cidade }\end{array}$ & Obras por regional \\
\hline Total de votos & 503.266 & 124.320 & 92.724 \\
\hline Total de participantes & 172.938 & 124.320 & 25.378 \\
\hline Valor do OPD & $\mathrm{R} \$ 20,2$ milhões & $\mathrm{R} \$ 50$ milhões & $\mathrm{R} \$ 50$ milhões \\
\hline $\begin{array}{l}\text { Processo de } \\
\text { definição do rol de } \\
\text { opções }\end{array}$ & $\begin{array}{l}\text { Critério técnico (definido } \\
\text { pela PBH) com posterior } \\
\text { colaboração popular } \\
\text { (participação da Comforça) }\end{array}$ & $\begin{array}{l}\text { Critério técnico } \\
\text { - Programa de } \\
\text { Estruturação Viária de } \\
\text { Belo Horizonte (Viurbs) }\end{array}$ & $\begin{array}{c}\text { Critério técnico - } \\
\text { Ouvindo, pontual } \\
\text { e indiretamente, a } \\
\text { população em alguns } \\
\text { canais de participação. }\end{array}$ \\
\hline $\begin{array}{l}\text { Fraudes ou falhas } \\
\text { noticiadas }\end{array}$ & Não & Sim & Não \\
\hline
\end{tabular}

Fonte: Adaptado de Belo Horizonte (2008a; 2007a; 2008b; 2009) e Nabuco (2008).

As entrevistas objetivavam conhecer em profundidade o processo de constituição histórica do OPD, bem como tentar apreender os sentidos que a democracia, a política, a cidadania e a participação têm para os atores entrevistados. Dessa maneira, a análise da prática do OPD poderia ser complementada, bem como o desenho institucional do OPD, poderia ser deslindado.

Diversos autores (FUNG, 2004; 2006; LÜCHMANN, 2009; BRASIL e QUEIROZ, 2010) sugerem que os formatos institucionais das instâncias participativas influem nos processos participativos. Segundo Brasil e Queiroz (2010, p. 7), tal influência pode "favorecer ou obstaculizar a participação cidadã. Ou seja, os desenhos institucionais dessas instâncias podem ser apontados como um dos fatores decisivos para a ampliação da participação e para sua qualidade e viés".

Para uma definição do desenho institucional do OPD, empregaremos os critérios propostos por Fung (2004): a) concepção do projeto; b) seleção e recrutamento dos participantes; c) tema e escopo da deliberação; d) modo deliberativo; e) recorrência e iteração; f) apostas; g) empoderamento; e h) monitoramento.

Critério (a): Em termos de concepção do projeto, Fung (2004) defende que podem existir quatro modelos orientadores: o de "fórum educativo" (que objetiva criar condições ideais para deliberação, para que os cidadãos possam formar, refinar e articular suas opiniões sobre determinado tema público); o de "conselho consultivo participativo" (que vai além da criação de condições ideais para a deliberação e envolve os tomadores de decisão, informando-os sobre as preferências da sociedade); o de "cooperação para a resolução participativa de problemas" (esse modelo prevê um relacionamento contínuo e simbiótico entre Estado e sociedade, para solucionar problemas complexos que não seriam resolvidos só com opiniões de especialistas ou da comunidade isoladamente); e o quarto modelo, chamado de "governança democrática participativa", é o mais ousado e busca, basicamente, incorporar as vozes dos cidadãos para determinação das agendas de políticas.

Ao analisar a concepção de projeto do OPD, percebemos o uso da ideia de deliberação de maneira constante nos discursos dos entrevistados.

Um grande diferencial em todas as experiências que eu conheço, e não estou dizendo que conheço todas, mas conheço muitas internacionais e nacionais, é que esse foi um processo deliberativo com relação ao orçamento público, os governos usam muito as TICS, a internet, como uma ouvidoria, ou como um objeto de consulta. Mas deliberação popular eu desconheço, que movimentou 10\% da base eleitoral de $\mathrm{BH}$ nas votações então... (Entrevistado 04 ) 
Foi, na verdade, uma ferramenta que facilitou a participação das pessoas. A internet hoje, ela permite que você possa tanto opinar sobre determinados assuntos como também deliberar sobre determinados assuntos. Como o OP de BH, deliberam sobre parte de um recurso, a PBH reserva um recurso para as pessoas opinarem no OP, então ao fazer o OPD, reservou uma outra parte de recursos para que outras pessoas, ou as mesmas pessoas, também participassem do processo, formou-se mais recursos para a participação popular na cidade. (Entrevistado 01)

A questão central aqui, em termos de concepção de projeto, é a definição do que é deliberação. Etimologicamente ${ }^{6}$, a palavra deliberação vem do latim deliberatio, de deliberare, ou seja, ponderar, considerar. E é formada por de (aqui entendida como "inteiramente"), mais liberare, uma alteração de librare, "balançar, pesar", de libra, "balança". Nesse sentido, considerando que os cidadãos irão ponderar entre um leque de opções, poderíamos considerar que, de fato, ocorre uma deliberação. Contudo, um ponto central que merece atenção é justamente a definição do leque de opções.

Diferentemente do OP Presencial, as opções do OPD não são selecionadas pela população. Tal fato despertou a atenção de um cidadão na primeira edição, em 2006, quando manifestou que:

Por exemplo quem propõe as obras para a votação? Não foi a população que definiu, como é feito no OP tradicional. Penso que se a população pudesse sugerir obras para a votação, o processo seria mais democrático. (Postagem 260, OPD 2006)

Sampaio $(2008 ; 2009)$ chama a atenção para essa dimensão do OPD, que pode influenciar sua real efetividade como mecanismo de fortalecimento da participação democrática. Best, Ribeiro, Matheus et al. (2010) entendem que há uma situação muito delicada no trato da deliberação virtual nas experiências de OPD no Brasil. Para os autores,

[...] há um trade-off entre a deliberação presencial e a ausência de um espaço de discussão no campo virtual, por um lado; por outro, como veremos, os cidadãos votam e assumem um papel de tomadores de decisão de fato, uma vez que as propostas mais votadas serão implementadas pela prefeitura (BEST, RIBEIRO, MATHEUS et al., 2010, p. 107).

Em documentos da PBH e mesmo no site do OPD, há um esforço para vincular o OP Regional ao OPD. Mas ambos têm natureza muito distinta e mesmo a lógica da complementaridade, defendida nas entrevistas feitas, não arrefecem o descompasso entre o modelo de definição das obras a ser votadas nas duas modalidades.

Com certeza, eu não tenho dúvidas disso, que são complementares [referindo-se à modalidade digital e presencial], não concorre de forma alguma porque as obras inclusive têm perfis diferentes. A obra do presencial é local, ela é ali próximo da casa, próximo do trabalho, e a do digital é uma obra pra cidade, a cidade inteira vai tá votando, vai tá participando e tem interesse naquele momento. Então é complementar, a obra do digital até pelo valor, ela não passaria num OP presencial né, no presencial os valores são bem menores, são obras mais pontuais, não menos importantes, mas mais pontuais. (Entrevistado 02)

Em um projeto político democrático-participativo, a concepção do desenho institucional estaria mais alinhada ao modelo de governança democrática participativa, justamente por seu caráter empoderador. Para Fung (2004, p. 177), esse modelo oferece a oportunidade de "injetar a participação direta, mobilizada, deliberativa do cidadão na governança democrática" podendo, dessa maneira, "favorecer as vozes daqueles em desvantagem e assim oferecer um antídoto procedimental que aumenta a equidade da legislação e da elaboração de políticas". No atual formato, o OPD mais se aproxima do modelo de conselho consultivo participativo.

\footnotetext{
${ }^{6}$ Conforme consulta realizada em: http://origemdapalavra.com.br/pergunta/origem-da-palavra-deliberacao/
} 
participativo digital

Critério (b): A seleção e o recrutamento de participantes deve ser aberto a todos, como advoga Fung (2004). Contudo o autor lembra que os "que comparecem são tipicamente os que possuem melhores condições de vida - ricos, instruídos e profissionais - em relação à população da qual provêm" (FUNG, 2004, p. 178). Seguindo com sua análise, Fung (2004) assevera que "praticamente todas as formas de participação política exibem padrões de participação que favorecem pessoas de status elevado, e as formas mais exigentes tendem a exacerbar este viés" (FUNG, 2004, p. 178).

A posição de Fung (2004) não se aplica certamente à experiência do OP Regional e mesmo ao OP historicamente. O que se nota na prática e na literatura, ao menos nos casos brasileiros, é justamente o oposto (MARQUETTI, CAMPOS e PIRES, 2008; AVRITZER e NAVARRO, 2003; SANTOS, 2002; FEDOZZI, 2007).

A baixa participação das classes média e alta no OP foi um dos pontos considerados no desenvolvimento do OPD. O argumento presente nas entrevistas e documentos pesquisados deixa clara a opção por inserir novos públicos no debate do orçamento municipal. Segundo a Entrevistada 04, a ideia era oferecer novos custos de participação e ver se tal mudança atraía outros públicos, principalmente os jovens e a classe média.

Tem um custo na participação, as pessoas nem sempre estão disponíveis. Alguns segmentos têm uma forma de participação e de fazerem valer seus direitos, diferente, existem outros mecanismos de aproximação com o poder, lobbys ou não. Mas, então, se percebia que, muitas vezes, o representante ia a um conselho, às vezes também estava em outro conselho e isso, obviamente, pode ser interessante porque ele consegue ter uma visão mais ampla; mas, naquele momento, especificamente na PBH, havia um objetivo e um interesse em ampliar a participação e trazer outros segmentos também para discutir o orçamento público, em especial a juventude, que participa muito pouco, muito pouco. Se você for olhar as características demográficas dos participantes em todos os processos, normalmente eles têm uma faixa etária mais alta. Enfim queria-se trazer a juventude e queria-se também trazer a classe média, dois segmentos que não participavam e ver se o custo da participação, em termos do tempo, era de fato um fator relevante que justificava a não participação. Além do mais, também uma nova linguagem que, especialmente para a questão da juventude, que talvez fosse uma linguagem mais próxima e que permitisse que criasse interesse de participação, esse foi talvez a grande questão que fez a PBH testar as ferramentas das TICs em um processo participativo. (Entrevistado 04)

Em BH, temos o OP desde 93; então de lá para cá a gente não teve nenhuma interrupção no processo do OP. Mas sempre existiu um certo desejo da PBH de buscar incorporar outros segmentos na participação popular de BH. O segmento da juventude, o segmento da classe média, que normalmente não participa do processo presencial. Então o nosso processo de OP, que a gente chama de regional, que é o presencial, é um processo que dura em torno de 9 meses, então a participação presencial ela requer do cidadão um desprendimento muito grande para este processo coletivo e nem todo mundo se dispõe a isso. Então ele vem neste sentido de agradar, de somar valor ao OP [...]. Ele vem com esse mote de agregar mais pessoas a esse processo de participação na gestão da cidade. (Entrevistado 01)

Ainda que a ideia de seleção de públicos que agregassem novos atores, tenha estado presente nas falas de todos os entrevistados e em documentos institucionais, podemos notar que a questão da articulação política e da formação de grupos "cristalizados" no OP Regional, também serviram de motivação. 
Ele foi implantado na Prefeitura em 2006, a partir do desejo, na época da Administração Pública, de ampliar o evento do orçamento participativo. Ele ficou concentrado num grupo de pessoas que se disponha a isso, $e$ O OP digital buscava ampliar a participação de pessoas que não têm disponibilidade de se deslocar no lugar e trabalhar. O OP presencial também já tinha alguns vícios, tipo "rixas eleitorais das regionais". Era muito preso às administrações regionais, não às Administrações Regionais em si, mas às lideranças regionais. E o Orçamento Participativo Digital de Belo Horizonte, que é uma cidade que presa muito pela inclusão digital, permitiria inclusão no processo de participação de pessoas que não teriam acesso a estas, vamos dizer organizações regionais, que dominam o orçamento presencial, isso é a motivação do OP digital. (Entrevistado 02)

Ainda que não haja dados disponíveis sobre o perfil do participante do OPD, fica claro, pela análise dos debates, que o objetivo de inclusão da classe média foi atingido. Nos debates analisados, principalmente na edição 2008, o embate entre "ricos e pobres" estava presente.

Galera, vamos retomar a vantagem da OBRA 4. Absurdo justamente a região melhor favorecida em acesso à internet não conseguir se mobilizar a contento... Lamentável. (Postagem 0038, OPD 2008)

Com o embate entre classes, emergiu, conforme manifestado na postagem acima, um debate sobre o acesso à internet como determinante da votação. Pessoas com maior poder aquisitivo poderiam, por ter mais acesso à internet, por exemplo, ser as grandes favorecidas no pleito das obras do OPD, de acordo com Fung (2004). Contudo, contrariando a lógica do autor, o que se notou foi a vitória, no caso do OPD 2008, por exemplo, de obras em locais de classes populares, que venceram com base em muita mobilização e articulação entre movimentos.

O método principal de acesso, o título de eleitor, também foi um critério de seleção. $E$ foi muito questionado por pessoas que não residiam em Belo Horizonte, mas usavam constantemente os serviços da cidade e se viam no direito de votar, vislumbrando as obras como pertencentes à Região Metropolitana:

O problema que a MAIORIA das pessoas AFETADAS pelo trânsito na praça são vicente é residente em contagem o que afeta diretamente na votação, essas pessoas deveriam ter o direito de votar!!!!!!! (Postagem 0729, OPD 2008).

Espero por essa obra há pelo menos 15 anos. E para o meu desespero, não posso votar, visto que meu título é de Contagem? Por quê isso? Nas eleições passadas, o Aécio apoiou a Prefeita eleita Marília Campos. A maioria das pessoas que transitam por ali, votam em Contagem...cadê a parceria?! Não acho justo a obra do Belvedere estar na frente... (Postagem 0618, OPD 2008, grifos adicionados).

E o processo de seleção, baseado no título de eleitor, gerou questionamentos até por parte do Ministério Público, gerando debates sobre a segurança do sistema de votação. O que poderia ser entendido como uma fragilidade do desenho institucional do OPD.

[O processo] ainda tá em maturação, outro dia estava expondo para o pessoal de João Pessoa que veio nos visitar que o processo está em crescimento, ao que vem a maturidade. Foi uma demanda lá inicial de se fazer um sistema, isso foi feito, um sistema que era ao mesmo tempo sistema de informação e era voto, era tudo junto. Depois evoluiu um pouquinho, na segunda demanda para fazer a votação, evoluiu para questão de segurança e acessibilidade, buscando que ele permitisse o acesso por telefone e agora está evoluindo novamente. Em, principalmente, termos de segurança, para evitar questionamento do Ministério Público [...]

Entrevistador: Ah e teve questionamento do MP?

Entrevistado: Sim, ele questionou em função de uma lacuna do TRE, que nos entrega os dados com três meses de diferença, onde tem três meses de movimentação, na base eleitores que a gente não tem. Gerou uma situação, então hoje a gente tem que evoluir para tentar manter o OPD atrativo, fácil e aumentar a segurança. (Entrevistado 02) 
Critério (c): Depois de definir o viés do projeto e a seleção dos participantes, é importante determinar o que será deliberado, ou seja, o tema e o escopo da deliberação. Para Fung (2004), a deliberação pública é habitualmente considerada, completamente, genérica no sentido de que sua estrutura, regras e benefícios são tidos como dependentes de tópicos particulares.

Em documentos analisados, a PBH informa que:

A Prefeitura seleciona os empreendimentos do OP Digital considerando a viabilidade técnica, a disponibilidade orçamentária e as demandas encaminhadas aos diversos canais de participação instituídos na cidade, como: OP Regional: obras que não são aprovadas no OP devido ao valor; Obras que foram indicadas pela população na primeira edição do OP Digital 2006 e não foram aprovadas; Demandas encaminhadas pelos cidadãos às Regionais; Demandas indicadas nos encontros da Gestão Compartilhada; Estudos já desenvolvidos pelos órgãos da Prefeitura, como Urbel, Viurbs e Sudecap.

Essa característica é determinante para se compreender a dinâmica do OPD. Os temas que irão ser foco dos debates não são decididos pela população, como no OP presencial. De acordo com Fung (2004), em um nível menos abstrato do desenho institucional, a escolha do tema modela de modo importante a operação do canal de debate e deliberação.

Tal situação é notada, nitidamente, nos debates entre as três edições do OPD. O formato de deliberação de obras por regionais, por exemplo, faz que os debates se concentrem entre pessoas de uma mesma regional. As obras são mais próximas, mais locais e o que se percebe é algo mais próximo de uma busca pelo melhor para uma dada coletividade. Obviamente, há disputa e concorrência, mas em um nível muito menor do que o observado na edição 2008, quando as obras viárias estruturantes foram apresentadas para deliberação.

Em 2008, a competitividade foi exacerbada por um sentimento bairrista, reconhecido até mesmo em comunidades virtuais, como o Orkut.

Daniel Matheus - 23/12/2008 - Esse OP Digital foi um absurdo! Como que colocam 5 obras VITAIS pro trânsito da cidade pra se escolher uma??? Essa votação promoveu o bairrismo. Um absurdo. É uma forma travestida de democracia.

Na entrevista 01, feita antes da edição 2011, os gestores envolvidos com o OPD já manifestavam preocupação com o formato da votação e as obras que seriam ofertadas para escolha da população.

[...] a ideia para 2011 é voltar ao primeiro modelo, de obras de médio porte por regional. Já aumentando o valor das obras de médio nas regionais, colocando uma obra por regional. O modelo que a gente teve de obras estruturantes a gente avaliou que foi interessante, mas é uma discussão mais difícil de fazer na cidade. Uma obra viária é um assunto mais árido para se debater. Quanto você traz um elemento mais próximo das pessoas facilita mais a discussão. [...] (Entrevistado 01)

Best, Ribeiro, Matheus et al. (2010, p. 117) questionam a forma da definição das obras, comparando com o modelo presencial, em que todas as etapas são definidas pela população com os técnicos municipais, inclusive quais obras irão para votação:

No OP presencial todas as etapas são definidas pelos cidadãos em conjunto com a Prefeitura, ou seja, desde a escolha das obras para a votação até o monitoramento. No caso de Belo Horizonte, a Prefeitura propôs os projetos que seriam votados pelos cidadãos na deliberação online. Portanto, podemos nos questionar se eles continuarão com este poder de determinação das obras a serem votadas no próximo OP Digital, ou será que a sociedade civil clamará por este direito de indicar obras como já ocorre no OP Presencial, em que todas as decisões, desde as propostas até as escolhas das obras e monitoramento, são definidas pelos cidadãos?

O questionamento de Best et al. (2003) se o formato de definição das obras seguiria com a PBH ou se a população iria clamar essa possibilidade, pode ser respondida atualmente, após a votação da edição 2011: Nada mudou e as obras, o "cardápio" 
continua sendo definido pela $\mathrm{PBH}$. E, ao que parece, isso não tem agradado a sociedade que, em algumas manifestações na internet, expressa sua insatisfação com as obras selecionadas para votação:

O orçamento participativo é uma iniciativa dos governos do PT. Há alguns anos se tornou digital, uma experiência interessante. O prefeito Lacerda não teve coragem de acabar com ele, mas tratou de torná-lo ridículo. Adotou mesmo o modelo Aécio-Anastasia: muita propaganda e pouco ou nada feito. A notícia abaixo não informa quem selecionou as obras que serão submetidas a votação, mas o nível baixou sensivelmente na administração Lacerda. Há até uma "construção de rotatória" na lista. Chama atenção a inclusão de implantação de câmaras de monitoramento (1984) como opção para quase todas as regiões. Difícil imaginar que numa cidade com tanta coisa para ser feita a instalação dessas câmaras - caras e já objeto de denúncia de corrupção - seja considerada prioridade. Inversamente, embora a cidade seja dramaticamente carente de espaços públicos, há na lista só uma obra de criação de praça e outra de instalação de um parque! Faz sentido: a administração Lacerda é $100 \%$ voltada para construção de hotéis e obras para os turistas da copa da máfi(f)a, não sobram recursos para obras de interesse da população. Dezesseis das 36 obras são de "requalificação" ou "revitalização" - nomes pomposos para manutenção. Isso é opção? Se a população não escolher essas obras, a Prefeitura vai deixá-las deteriorar? Há até "reforma de calçadas do hipercentro" na lista! Antigamente, a Prefeitura fazia isso como obrigação, não era preciso que a população implorasse. Mas antigamente também prefeito não vendia rua, não vendia todos os imóveis públicos disponíveis, não autorizava urbanização de áreas verdes nem proibia uso coletivo de espaços públicos. Apenas meia dúzia de obras mereceria constar da consulta popular, se ela não fosse um instrumento de propaganda de Lacerda, o prefeito milionário que não mora na cidade que administra.

Nota-se uma série de evidências de que esse modelo deve ser repensado para as próximas edições.

Critério (d): O modo deliberativo, ou seja, o "como" de um projeto que envolva a participação democrática. Essa dimensão se relaciona ao estilo das discussões e à organização (FUNG, 2004). Em termos organizativos e operacionais, as três edições apresentam características similares ao possibilitar a votação pela internet ou pelo telefone (caso da edição 2008 ) em um conjunto de obras pré-selecionadas.

O que se percebe, ao analisar o desenho institucional das três edições do OPD, é que o espaço para debates e argumentação foi estruturado de modo muito limitado. Sampaio, Maia e Marques (2010, p. 446), ao analisarem os espaços e discursos da edição 2008 do OPD, concluem que os espaços destinados ao debate argumentativo no desenho da edição 2008 não foram incentivados pela $\mathrm{PBH}$.

Os resultados apontam que os aspectos discursivos concernentes à reciprocidade e à reflexividade se mostraram relativamente escassos; entretanto, o respeito pelos outros interlocutores, bem como a construção da justificativa dos pontos de vista expressos no fórum, alcançaram índices elevados, mesmo não havendo empowerment da ferramenta ou incentivo por parte da Prefeitura. Conclui-se que a internet pode, efetivamente, oferecer ambientes voltados para o estabelecimento de trocas discursivas qualificadas e que, mesmo nos casos onde há baixos índices de deliberatividade, há progressos importantes do ponto de vista do aprendizado a que são expostos os usuários.

Os canais existentes resumem-se a um espaço para postagem de mensagens de apoio, sugestões ou críticas. São criados tópicos, pela própria PBH, por obras, ou por temas específicos.

Os canais de debate e a forma como a deliberação ocorre podem, na visão de Fung (2004), ajudar os indivíduos participantes a aclarar as próprias ideias. Além disso, Fung (2004) defende que a lógica do melhor argumento pode (e deve) deixar de lado outros métodos de decisão, como a confiança na autoridade, no status, nos números, no dinheiro ou no desempenho.

Sampaio, Maia e Marques (2010, p. 472), afirmam que:

Considerando-se essas dificuldades técnicas e a ausência de direcionamento por parte da administração municipal, podemos dizer que ficaram acima das expectativas os valores de respeito e de argumentação. Como dito, acreditamos que as principais indicações para isso estejam no fato de as ferramentas 
de discussão estarem no mesmo site que a ferramenta de votação e de esta estar decidindo obras a respeito do trânsito, um tema que aflige a todos os residentes de uma cidade. Esses resultados, levando-se em conta o caráter assíncrono da internet, podem ter grande valor político. Afinal, as mensagens continuam disponíveis para outras pessoas que visitem o site posteriormente. Para esse terceiro cidadão (o que visita o fórum após as discussões), dois argumentos iniciais, que não se respondem mutuamente, mas que apresentam posições baseadas em razões, poderão formar um "debate" no processo cognitivo do terceiro envolvido. Logo, mesmo aqueles que apenas observam o debate, os lurkers, poderiam se beneficiar com a leitura das mensagens.

Corrobora-se o que dizem Sampaio, Maia e Marques (2010), ao entender que mesmo os limitados canais oferecidos pela PBH para o processo de debate e de deliberação podem contribuir para a criação de um espaço de discussão.

Critério (e): A dimensão chamada de recorrência e iteração refere-se ao tempo. Quando e com que frequência as reuniões e os encontros deliberativos ocorrerão? Para Fung (2004), a ideia de que "mais é melhor" no impulso participativo é equivocada, à medida que a frequência dos encontros para debate e deliberação de um determinado tema deve advir de seus propósitos.

Nesse caso, o OPD seguiu uma periodicidade bianual, tendo sido realizadas edições em 2006 e em 2008, e a última em 2011, destoando da regularidade de a cada dois anos haver um pleito. Diferentemente do OP Regional, não há um regimento interno elaborado pelos cidadãos que estabeleça com clareza as regras que guiarão o OPD, inclusive sua periodicidade. $\mathrm{O}$ que deixa o processo um pouco volátil aos desejos da $\mathrm{PBH}$, a organizadora dos pleitos digitais.

Critério (f): Fung (2004) defende que o engajamento das pessoas depende do interesse, por conta disso, o planejamento de uma ação participativo-deliberativa deve levar em conta as apostas que as pessoas fazem na deliberação. "A discussão diz respeito a algum assunto que afeta o bem-estar ou as crenças arraigadas dos participantes? Estão os participantes interessados porque o assunto se tornou uma controvérsia pública?" São algumas reflexões que Fung (2004, p. 181) sugere.

Fung (2004) entende que deliberações com base na dimensão das apostas, ou seja, por que participar, podem ser "frias ou quentes". A ideia de uma deliberação fria refere-se aos participantes com baixa aposta, sem posições fixas e desapaixonados. Posições opostas seriam as deliberações quentes, obviamente. Fung (2004) defende que deliberações quentes são mais ricas para o processo participativo. Quanto mais apaixonado o engajamento, maior a possibilidade de um trabalho criativo e detalhado. Além disso, a possibilidade de um acompanhamento mais vigoroso e interessado da decisão deliberada, após a implantação, também é maior.

No caso do OPD, nota-se que os debates se aproximaram mais da concepção "quente" de Fung (2004). O empenho das pessoas, entretanto, foi variável em termos de mobilização em cada uma das edições. Belo Horizonte (2008a, p. 12) afirma que

[...] a mobilização da comunidade foi expressiva e responsável por viradas espetaculares na votação de obras. No Mercado Central, os dois computadores instalados na Praça do Abacaxi foram o ponto de partida para tirar a reforma da Praça Raul Soares do terceiro lugar e levar a obra à vitória na regional Centro-Sul.

A mobilização e, aparentemente, o nível de aposta das pessoas, foi-se arrefecendo ao longo das edições, sobretudo pela não realização de algumas obras, como podemos notar em uma postagem no debate da edição 2011:

\begin{abstract}
Acho que de nada vale o O.P. lembro bem de um que teve que era a restruturaçãcao da Pça. Sao vicente (parte do anel rodoviario) ou a alca do BH Shopping - Nova Lima... O bairro aqui fez uma mobilizacao para ganhar porque so quem mora aqui sabe o que passamos, dito e feito, vencemos o OP que naquele ano era 1 obra por ano... a Pca Continua a mesma, a prefeitura diz que nosso OP ficou pendente por causa da reestruturacao do anel rodoviario.... ou seja, estamos esperando o anel ser reformado! (NUNCA) ja no Belvedere, a alca saiu a muito tempo.... Essas obras so visa melhorar interesses publicos e politicos!" (Postagem 0129, OPD 2011)
\end{abstract}

Critério (g): Quando os resultados das deliberações de uma dada iniciativa participativa influenciam as decisões públicas, podemos entender que houve um empoderamento. Este ocorre quando os resultados deliberativos influenciam as decisões públicas (FUNG, 2004). 
Analisando a experiência do OPD, pode-se concluir que as deliberações ou obras aprovadas são tomadas como prioridade para realização por parte da PBH. Segundo dados divulgados pela PBH:

Nas edições anteriores do OP Digital, foram aprovados 10 empreendimentos, sendo nove na edição do OP Digital em 2006 e um na edição do OP Digital 2008. Dos 10 empreendimentos aprovados, nove já foram concluídos e entregues à população e 296 mil pessoas participaram do processo.

Contudo, inclusive pela quantidade decrescente de participantes nas três edições do OPD, é provável que as pessoas não estejam notando empoderamento nessa ferramenta digital, como podemos ilustrar com algumas postagens:

acreditarei no OP quando vcs concretizarem a praça são vicente onde ja foi ganho o OP e vcs fizeram a obra que perdeu. (Postagem 0144, OPD 2011).

Até hoje nao sairam as obras da praça São Vicente, porque fazer outra votação? É uma perda de tempo absurda e desrespeito ao contribuinte. e ainda gastam mensagem de SMS pra avisar que esta ocorrendo a votação e incentivar a participação... (Postagem 0205, OPD 2011)

\section{CADÊ A OBRA DA PRAÇA SÃO VICENTE QUE GANHOU NO OP DE 2009? MAS O QUE FOI CONCLUÍDO FOI A SEGUNDA OBRA A DO BELVEDERE. NÃO VEJO NECESSIDADE DE FAZER UMA VOTAÇÃO PARA DECIDIR UMA OBRA. POIS VOCÊS FAZEM A QUE MAIS LHE CONVÉM. (Postagem 0233, OPD 2011)}

CRÍTICA: O processo democrático do voto é sem dúvida a melhor maneira de decidir sobre uma obra, priorizações e execução. CONTUDO, a não execução da obra vencedora de 2008 gerou desconfiança e falta de credibilidade no processo. Essa mancha é irreparável. (Postagem 0288, OPD 2011)

O descrédito gerado pela não realização de uma obra vencedora na edição 2008, objeto de grande mobilização popular, pode ter colocado em questão a percepção de empoderamento por parte da população.

Critério (h): A última dimensão refere-se ao monitoramento. Segundo Fung (2004), o monitoramento fortalece o processo participativo uma vez que favorece o aprendizado. Os participantes podem ver os resultados da deliberação e aprimorar o processo participativo; e, assim, adquirem ainda um "conhecimento experimentalmente embasado" (FUNG, 2004, p. 183), aprendendo na prática que tipo de decisão funciona ou não. Além disso, outro benefício do monitoramento é um favorecimento da accountability, que pressiona os representantes políticos a agirem com transparência, dando assim mais legitimidade ao processo.

Enquanto no OP Presencial a população fiscaliza e acompanha todas as fases do processo deliberativo, inclusive a realização das obras, por intermédio da Comforças, no caso do OPD isso não é claramente estabelecido.

Entrevistador: Em termos de acompanhamento das obras do OPD, ele é feito pela Comforça também?

Entrevistado: Na verdade a gente não estabeleceu. Como ele foi um processo da cidade inteira, quem é que vai acompanhar? O que acaba acontecendo é que quem toma conta disso são normalmente as pessoas que participam dos processos normais da cidade, das conferências, dos fóruns, então eles já falam disso. Então a Comforça, que é o grupo que faz o acompanhamento das obras nos regionais, acaba falando disso nas suas reuniões plenárias. Mas a ideia hoje é como a gente tem um grupo municipal, uma Comforça que tem representação das 9 regionais mais habitação, queremos que o grupo seja um pouco responsável por isso. Fora que a gente recebe no e-mail do OP várias pessoas dando sugestões ou falando, perguntando, que aí é o cidadão comum querendo saber. (Entrevistado 01) 
O que fica claro é que o processo de monitoramento não é efetivo no caso do OPD e isso pode gerar uma série de ruídos de comunicação entre a PBH e a sociedade. Se existisse uma comissão de monitoramento e acompanhamento estabelecida, com uma linha de atuação claramente definida pela própria população, é provável que a não realização da obra da praça São Vicente pudesse ter sido mais bem digerida pela sociedade.

Analisando o OPD, à luz das dimensões propostas por Fung (2004), podemos então elaborar o seguinte gráfico representativo do desenho institucional do OPD:

Figura 8

Cubo democrático do OPD

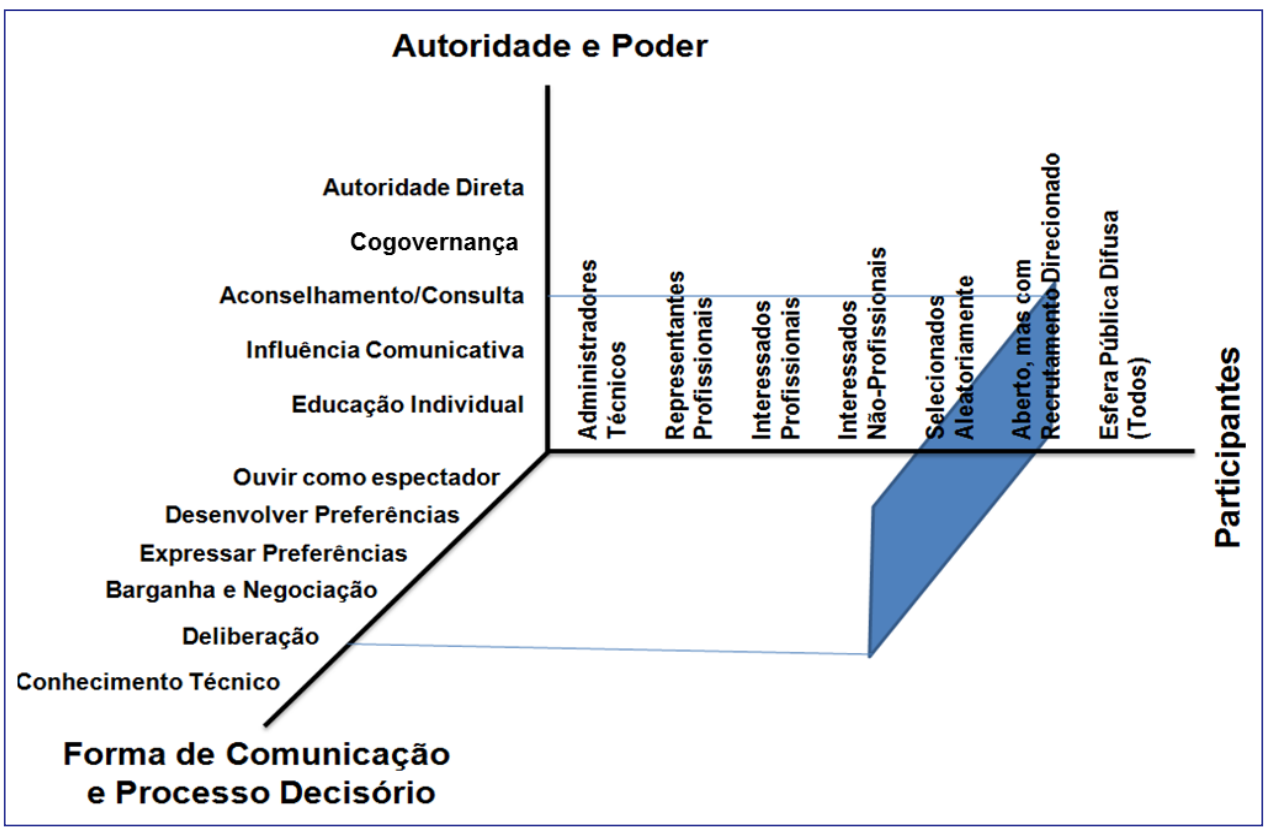

Fonte: Adaptado de Fung (2004).

Na Figura 8 é apresentada a representação do cubo democrático. No eixo "Autoridade e Poder", o desenho institucional do OPD se aproxima da ideia de "aconselhamento/consulta". Já o eixo "Participantes" é classificado como "aberto, mas com recrutamento direcionado" pois só os eleitores da cidade de Belo Horizonte podem participar do processo. Finalmente no eixo "Forma de Comunicação e Processo Decisório" é identificado como "deliberação" dado seu caráter efetivo de decisão sobre um dado tema ou obra.

\section{CONSIDERAÇÕES FINAIS}

Toda a tensão vivenciada pela gestão pública e discutida na parte introdutória deste artigo pode ser percebida na experiência do OPD, aqui analisada. A dinâmica produzida pelo desenho institucional adotado pela PBH no OPD coloca em questão o potencial desse recurso digital em combinar, ao mesmo tempo, condições para atender a demanda participativa e gerencialista que pressionam a gestão pública.

Considerando que o objetivo desta pesquisa foi analisar o OPD por meio de seu desenho institucional, a principal conclusão que pode ser apontada é a de que a configuração do desenho institucional é determinante para a qualidade da participação democrática de uma iniciativa como o OPD. Se entre alguns teóricos (como PUTNAM, 1993) há a ideia de que o desenho institucional apresenta fraca influência sobre a participação da sociedade na esfera pública, essa conclusão definitivamente não se aplica ao caso do OPD. Como um recurso dinâmico, o OPD apresentou três diferentes desenhos institucionais em suas três 
edições. Se esse fato, de certo modo, tornou mais complexo qualquer esforço comparativo, ao mesmo tempo apresentou a possibilidade de se compreender e associar os discursos e comportamentos dos cidadãos nas três edições. Manifestações, como enfrentamento verbal, posições de disputa e mesmo um "bairrismo", podem ser notadas nas postagens analisadas.

O estudo efetuado por Fung (2004) com a análise das dimensões: a) concepção do projeto; b) seleção e recrutamento dos participantes; c) tema e escopo da deliberação; d) modo deliberativo; e) recorrência e iteração; f) apostas; g) empoderamento; h) monitoramento; forneceu importantes elementos para a classificação e o desenho do OPD no cubo democrático.

Quando o desenho institucional se propôs, na visão da PBH (BELO HORIZONTE, 2008a), a fazer o debate de uma grande obra viária estruturante para a cidade, de maneira que todos pudessem pensar "a polis" de modo integrado, o que se notou foi uma verdadeira disputa bairrista, em alguns casos, com referências à condição econômica das pessoas (ricos versus pobres, trabalhadores versus empregadores etc.). A visão de Silva (2003) de que o OP pode criar uma nova arena de discussão, na qual os espaços para se moldar as relações entre as classes e mesmo alterar os efeitos do conjunto das estruturas de maneira mais democrática, se confirma. Curiosamente, as diferenças entre classes se apresentam com um relevo muito mais destacado no OPD. Enquanto o OP Presencial é visto como uma arena mais homogênea, em que pessoas, em sua maioria de uma mesma classe social, procuram participar das decisões públicas, o OPD mostra-se muito mais heterogêneo (no sentido de que pessoas de realidades distintas partilham o momento de debate no OP presencial).

Nogueira (2005, p. 161) afirma que "a realidade concreta foi-se encarregando de mostrar que os canais de participação são espaços em que se manifestam intensas demandas e pressões sobre o governo e que os conflitos resultantes desse processo precisam ter regras democráticas para que, de fato, se constituam em possibilidades de democratização". O regramento do OPD, envolvido diretamente com a ideia do desenho institucional, é que não foi, em nenhuma das edições, debatido com a população.

Diferentemente do que ocorre no OP Presencial, a versão digital é mais contida, menos política em termos de design institucional. O que se nota é que o potencial político foi represado pelo desenho institucional. Conflitos latentes, disputas políticas entre classes, debates e mesmo um espaço onde houvesse a profusão de uma discussão negocial e explicitação de diferentes interesses (NOGUEIRA, 2005) poderiam ser vivenciados intensamente nessa modalidade de OP, uma vez que, enquanto os debates nas assembleias presenciais seguem, praticamente, um mesmo tom, vivenciados por pessoas de um mesmo extrato social, o OPD rompe a barreira física, possibilitando que um morador da Zona Sul (de maior poder aquisitivo) exponha sua ideia, manifeste sua opinião e debata com um morador de uma região mais pobre, sem a necessidade de ir a um centro comunitário na periferia. Esse potencial, no entanto, é limitado pelo desenho institucional desenvolvido.

Um dos gestores entrevistados apresentou a argumentação de que uma possível causa para essa limitação, para além do projeto político, é a tecnologia. Para ele, o desenvolvimento de uma lógica mais participativa e mesmo descentralizada (como ocorre no OP presencial) estaria limitada pelas condições técnicas oferecidas na atualidade. Ainda que seja um argumento legítimo, discorda-se dessa proposição, pois se entende que existem, sim, condições técnicas para uma radicalização do OPD (poderia haver, por exemplo, um debate prévio, online, sobre as regras do processo, sobre a definição das obras a serem votadas, sobre um formato de controle ativo das obras posteriormente).

No último plano de análise, as conclusões articulam as principais contribuições do OPD para o modelo de democracia participativa. Partindo de um prisma de análise da gestão, as contribuições identificadas referem-se ao oferecimento de novos custos de participação (que fez, efetivamente, que novos atores participassem do processo deliberativo) e a transparência das obras (embora seja muito pouco em termos de controle social, isso mostra que, potencialmente, as TIC podem contribuir nessa seara, prestando informações para o fortalecimento de um modelo democrático participativo). Deve-se reconhecer, contudo, o risco da "comoditização" da participação democrática, que não traria melhorias na qualidade da democracia. Ao optar por um design institucional que tem grande foco no voto, e menos no debate, a PBH incorre no risco de esvaziamento do sentido democrático do OPD. Algo similar ao que vivenciamos no plano presencial, em que os cidadãos e a mesmo a mídia direcionam grande foco para as eleições que ocorrem a cada dois anos, esquecendo-se de que a democracia e a participação se fazem no dia a dia. Observando a prática dos cidadãos, a principal contribuição identificada foi a ressonância da participação digital nas ações presenciais de articulação, mobilização e participação da sociedade.

Recomenda-se que em pesquisas futuras sejam exploradas as relações entre o desenho institucional e a queda do número de participantes nessa iniciativa. 


\section{REFERÊNCIAS}

ABREU, J. C. A.; PINHO, J. A. G. Sentidos e significados da participação democrática através da internet: uma análise da experiência do orçamento participativo digital. Rev. Adm. Pública, v. 48, n. 4, p. 821-846, 2014.

AVRITZER, L. Instituições participativas e desenho institucional: algumas considerações sobre a variação da participação no Brasil democrático. Revista Opinião Pública, v. 14, n. 1, p. 44-64, 2008.

AVRITZER, L.; NAVARRO, Z. (Org.). A inovação democrática: o orçamento participativo no Brasil. São Paulo: Cortez, 2003.

BELO HORIZONTE (Município). Caderno de metodologia. Belo Horizonte: Prefeitura Municipal, 2007a.

BELO HORIZONTE (Município). Relatório do Prêmio do Observatório de Democracia Participativa - OIDP. Belo Horizonte: Prefeitura Municipal, 2007b.

BELO HORIZONTE (Município). Anuário estatístico 2008. Belo Horizonte: Prefeitura Municipal, 2008a.

BELO HORIZONTE (Município). Relatório da Secretaria Municipal Adjunta de Planejamento. Belo Horizonte: Prefeitura Municipal, 2008b.

BELO HORIZONTE (Município). Relatório Estatístico: 2009. Belo Horizonte: Prefeitura Municipal, 2009.

BEST, N. et al. Internet e a participação cidadã nas experiências de orçamento participativo digital no Brasil. Cadernos PPG-AU/FAUFBA, n. 9, p. 105-124, 2010.

BONI, V.; QUARESMA, S. J. Aprendendo a entrevistar: como fazer entrevistas em ciências sociais. Revista Eletrônica dos Pós-Graduandos em Sociologia Política da UFSC, v. 2, n. 1, p. 68-80, 2005.

BRASIL, F. P. D.; QUEIROZ, L. S. Gestão metropolitana e participação: uma análise do Conselho Deliberativo de Desenvolvimento Metropolitano da RMBH. Revista E-Metropolis, n. 1, p. 6-29, 2010.

CABRAL, E. R.; GOMES, S. C.; ARAUJO, F. F. Organização e pressão política do empresariado industrial brasileiro frente à regulação ambiental: estratégias da Confederação Nacional da Indústria CNI. In: EnANPAD, 34.; 2010, Rio de Janeiro. Anais... Rio de Janeiro: ANPAD, 2010.

CUNHA, E.; ALLEGRETTI, G.; MATIAS, M. As tecnologias de informação e comunicação na gramática dos orçamentos participativos: tensões e desafios de uma abordagem essencialmente subordinada. In: CONGRESSO COMUNICAÇÃO E POLÍTICA; 2007, Belo Horizonte. Anais... Belo Horizonte: Universidade Federal de Minas Gerais, 2007.

CUNHA, M. A.; COELHO, T. R.; POZZEBON, M. Internet e participação: o caso do orçamento participativo digital de Belo Horizonte. Revista de Administração de Empresas, v. 54, n. 3, p. 296-308, 2014.

CUNHA, M. A.; POZZEBON, M. O uso das tecnologias da informação e comunicação para melhoria da participação na tomada de decisão pública. In: EnANPAD, 33.; 2009, São Paulo. Anais... São Paulo: ANPAD, 2009.

DENZIN, N. K.; LINCOLN, Y. S. (Eds.). Handbook of qualitative research. 2. ed. Thousand Oaks, CA: Sage, 2000.
FACHIN, O. Fundamentos de metodologia. São Paulo: Saraiva, 2001.

FEDOZZI, L. Observando o orçamento participativo de Porto Alegre: análise histórica de dados - perfil social e associativo, avaliação e expectativas. Porto Alegre: Tomo, 2007.

FRANCKINI, T. M. et al. Participação e representações alternativas nas democracias contemporâneas: dois fenômenos, uma abordagem. In: SEMINÁRIO INTERNACIONAL MOVIMENTOS SOCIAIS PARTICIPAÇÃO E DEMOCRACIA, 1.; 2010, Florianópolis. Anais... Florianópolis: Universidade Federal de Santa Catarina, 2010.

FREY, K. Desenvolvimento sustentável local na sociedade em rede: o potencial das novas tecnologias de informação e comunicação. Revista de Sociologia e Política, n. 21, p. 165-185, 2003.

FUNG, A. Receitas para esferas públicas: oito desenhos institucionais e suas consequências. In: COELHO, V. S. P.; NOBRE, M. (Org.). Participação e deliberação: teoria democrática e experiências institucionais no Brasil contemporâneo. São Paulo: Ed. 34, 2004. 368 p.

FUNG, A. Varieties of participation in complex governance. Harvard University Forthcoming. Public Administration Review, v. 66, n. Supplement 1, p. 66-75, 2006.

GONÇALVES, H. L. Uma visão crítica do orçamento participativo. Rio de Janeiro: Lumen Juris, 2005.

LÜCHMANN, L. H. H. O desenho institucional dos conselhos gestores. In: LYRA, R. P. (Org.). Participação e segurança pública no Brasil: teoria e prática. João Pessoa: Universidade Federal da Paraíba, 2009. 377 p.

MARQUES, F. P. J. A. Participação política e desenho institucional: uma proposta para a concepção de mecanismos participativos. Ciências Sociais Unisinos, v. 46, n. 2, p. 140-151, 2008.

MARQUETTI, A.; CAMPOS, G. A.; PIRES, R. Democracia participativa e redistribuição: análise de experiências de orçamento participativo. São Paulo: Xamã, 2008.

MILANI, C. O princípio da participação social na gestão de políticas públicas locais: uma análise de experiências latino-americanas e europeias. Rev. Adm. Pública, v. 42, n. 3, p. 551-579, 2008.

MONTEIRO, J. V. A pressão pelo crescimento: desonerações \& reformas. Rev. Adm. Pública, v. 41, n. 1, p. 161-175, 2007.

NABUCO, A. L. Democracia eletrônica: Orçamento Participativo Digital de Belo Horizonte. In: SEMINÁRIO INTERNACIONAL DO ORÇAMENTO PARTICIPATIVO; 2008, Belo Horizonte. [s.n]. Belo Horizonte: [s.n], 2008.

NOGUEIRA, M. A. Em defesa da política. São Paulo: Senac, 2004.

NOGUEIRA, M. A. Um Estado para sociedade civil: temas éticos e políticas da gestão democrática. 2. ed. São Paulo: Cortez, 2005.

NUNES, J. A. Da democracia técnica à cidadania cognitiva: a experimentação democrática nas "sociedades do conhecimento". Coimbra: Centro de Estudos Sociais, 2006.

PINHO, J. A. G. Sociedade da informação, capitalismo e sociedade civil: reflexões sobre a política, internet e democracia na realidade brasileira. Revista de Administração de Empresas, v. 51, n. 1, p. 98-106, 2011. 
PORTILHO, F. Sustentabilidade ambiental, consumo e cidadania. São Paulo: Cortez, 2005.

PUTNAM, R. Making democracy work: civic traditions in modern Italy. Princeton, NJ: Princeton University Press, 1993.

RICHARDSON, R. J. et al. Pesquisa social: métodos e técnicas. 3. ed. São Paulo: Atlas, 2007.

ROSAS, F.; SANTOS, B. S. Pela mão de Marx: mercado, Estado e sociedade civil no século XXI. In: SEMINÁRIO FEUC/CES; 2009, Coimbra. [s.n]. Coimbra: Centro de Estudos Sociais, 2009.

SAMPAIO, R. C. Diferentes modos de participação: alguns impactos da introdução da internet no orçamento participativo de Belo Horizonte. Comunicação \& Política, v. 27, n. 2, p. 51-78, 2008.

SAMPAIO, R. C. Governança eletrônica no Brasil: limites e possibilidades introduzidos pelo orçamento participativo na internet. Planejamento e Políticas Públicas, n. 33, p. 123-144, 2009.

SAMPAIO, R. C. Instituições participativas online: um estudo de caso do orçamento participativo digital. Revista Política Hoje, v. 20, n. 1, p. 467-512, 2011.

SAMPAIO, R. C.; MAIA, R. C. M.; MARQUES, F. P. J. A. Participação e deliberação na internet: Um estudo de caso do Orçamento Participativo Digital de Belo Horizonte. Revista Opinião Pública, v. 16, n. 2, p. 446-477, 2010.
SANCHEZ, F. Orçamento participativo: teoria e prática. São Paulo: Cortez, 2002.

SANTOS, B. S. Democratizar a democracia: os caminhos da democracia participativa. Rio de Janeiro: Civilização Brasileira, 2002. (Coleção Reinventar a Emancipação Social).

SANTOS, M. E. P.; SAMPAIO, R. M.; ROSSI, R. A. Análise comparativa do significado da participação nos comitês das bacias dos rios Paraguaçu e São Francisco. In: ENCONTRO DA ANPPASS, 3.; 2006, Brasília. Anais... Brasília, DF: Anppass, 2006.

SERAFIM, L. Controle social nas agências reguladoras brasileiras: entre projetos políticos e modelo institucional - A ANEEL nos governos FHC e Lula (1995-2005). 207 f. Dissertação (Mestrado em Ciência Política) - Universidade Estadual de Campinas, Campinas, 2007.

SILVA, I. G. Democracia e participação na "reforma do Estado". São Paulo: Cortez, 2003.

TRIVIÑOS, A. N. S. Introdução à pesquisa em ciências sociais: a pesquisa qualitativa em educação. São Paulo: Atlas, 1987.

WEST, D. M. Digital government: technology and public sector performance. Princeton: Princeton University Press, 2005.

ZANELLA, L. C. H. Metodologia de estudo e de pesquisa em administração. Florianópolis/Brasília: Universidade Federal de Santa Catarina/ Coordenação de Aperfeiçoamento de Pessoal de Nível Superior, 2009.

Júlio Cesar Andrade de Abreu

Doutor em Administração pela Universidade Federal da Bahia (NPGA/UFBA); Professor Adjunto na Universidade Federal Fluminense (UFF/ICHS/PPGA) Email: julioabreu@vm.uff.br 